\title{
Translation and Psychometric Evaluation of the Chinese Version of Functional Digestive Disorders Quality of Life Questionnaire
}

\author{
Liu Feng-bin • Jin Yong-xing • Wu Yu-hang • \\ Hou Zheng-kun • Chen Xin-lin
}

Received: 14 February 2013/Accepted: 23 September 2013/Published online: 8 November 2013

(C) The Author(s) 2013. This article is published with open access at Springerlink.com

\begin{abstract}
Background Few useful patient-reported outcomes scales for functional dyspepsia exist in China.

Aims The purpose of this work was to translate and crossculturally adapt the Functional Digestive Disorders Quality of Life Questionnaire (FDDQL) from the English version to Chinese (in Mandarin).

Methods The following steps were performed: forward translations, synthesis of the translations, backward translations, pre-testing and field testing of FDDQL. Reliability, validity, responsiveness, confirmatory factor analysis, item response theory and differential item functioning of the scale were analyzed.

Results A total of 300 functional dyspepsia patients and 100 healthy people were included. The total Cronbach's
\end{abstract}

Hou Zheng-kun is the co-first author.

L. Feng-bin $(\bowtie) \cdot J$. Yong-xing $\cdot$ H. Zheng-kun

Gastroenterology Department, First Affiliated Hospital,

Guangzhou University of Chinese Medicine,

Guangzhou 510405, Guangdong, China

e-mail: liufb163@163.com

J. Yong-xing

e-mail:223042515@qq.com

H. Zheng-kun

e-mail: fenghou5128@126.com

W. Yu-hang

Wuyi Hospital of Chinese Medicine, Jiangmen 529111,

Guangdong, China

e-mail:6079476@qq.com

\section{Xin-lin}

Department of Preventive Medicine and Health Statistics, College of Basic Medical Sciences, Guangzhou University of Chinese Medicine, Guangzhou 510006, Guangdong, China

e-mail: chenxlsums@126.com alpha was 0.932 , and split-half reliability coefficient was 0.823 with all test-retest coefficients greater than 0.9 except Coping With Disease domain. In construct validity analysis, every item correlated higher with its own domain than others. The comparative fit index of FDDQL was 0.902 and root mean square error of approximation was 0.076. Functional dyspepsia patients and healthy people had significant differences in all domains. After treatment, all domains had significant improvements except diet. Item response theory analysis showed the Person separation index of 0.920 and the threshold estimator of items was normally distributed with a mean of 0 and standard deviation of 1.27. The residuals of each item were between -2.5 and 2.5, without statistical significance. Differential item functioning analysis found that items had neither uniform nor non-uniform differential item functioning in different genders and age groups.

Conclusions The Chinese version of FDDQL has good psychometric properties and is suitable for measuring the health status of Chinese patients with functional dyspepsia.

Keywords Functional dyspepsia - Quality of life · Translations · Validation studies .

Cross-cultural comparison $\cdot$ Health outcomes

\section{Introduction}

Functional dyspepsia (FD) is characterized by symptoms including bothersome postprandial fullness, early satiation, epigastric pain and scorching heat with no evidence of organic damage [1]. FD is a common condition with a high prevalence throughout the world; according to research it has affected up to $29.2 \%$ of the global population [2, 3]. FD symptoms often impact aspects of the patients' health- 
related quality of life (HRQL), these including abdominal pain and indigestion, emotional distress, problems with food and drink, impaired vitality, and heavy economic burdens $[4,5]$. Consequently, the HRQL endpoint is critical in assessing the clinical outcomes of FD.

Numerous disease-specific scales have been developed for $\mathrm{FD}$, a few include quality of life in duodenal ulcer patients (QLDUP) [6], quality of life in reflux and dyspepsia (QOLRAD) [7], functional digestive disorders quality of life questionnaire (FDDQL) [8, 9], quality of life in peptic disease (QPD) [10], Nepean dyspepsia index (NDI) [11], and severity of dyspepsia assessment (SODA) [12], etc. So far, no Chinese version of these scales has been translated and validated. Considering that FD is also a very common disease in China, with a high prevalence of up to $18.92 \%$ [13], and also, few useful HRQL instruments for FD exist in clinical research and practice, the introduction of a Chinese FD HRQL instrument is urgent and necessary.

Functional digestive disorders quality of life questionnaire (FDDQL) is a disease specific scale originally developed in French and validated by Chassany Olivier et al. in 1998 [8, 9]. It aims to measure the specific physical, psychological, and perpetual impacts of FD and irritable bowel syndrome. The 5point Likert scale contains 43 items under eight subheadings, which are activities ( 8 items), anxiety (5 items), diet (6 items), sleep (3 items), discomfort ( 9 items), health perceptions (6 items), coping with disease ( 3 items) and impact of stress (3 items). A higher overall score indicates a better HRQL status. With the validity and reliability being evaluated, it has further been translated into Italian, Hungarian and Spanish, adapted for US, English, French and Canadian patients [8, 14], and applied in many clinical trials [15-17]. This study aims to translate and cross-culturally adapt the English version of FDDQL into Chinese (in Mandarin).

\section{Methods}

Participants

\section{Expert Panel}

The study group included one coordinator, four translators, three gastroenterologists, two nurses, two HRQL experts and one secretary. The group aimed to conduct and participate in each research stage, with the guidance of moderator (Prof. Liu Feng-bin) during the overall research process and translation procedures.

\section{Patients}

According to Rome III diagnostic criteria, functional dyspepsia (FD) must include one or more of the following: (a) bothersome postprandial fullness, (b) early satiation, (c) epigastric pain, and (d) epigastric burning, as well as no evidence of structural tissue damage (including upper endoscopy level) that is likely to explain the symptoms. The FD patients were divided into Postprandial Distress Syndrome (PDS) and Epigastric Pain Syndrome (EPS) as Rome III defined.

The inclusion criteria were: (a) the existence of FD defined by Rome III, (b) age range between 18 and 70 years, and (c) Chinese literate. The following were excluded: pregnant or lactating women, FD patients with disturbance of consciousness, mental illness or other specific diseases who cannot comprehend the scale. The diagnostic, inclusion and exclusion criteria applied for every step in the study.

Permissions for the Use and Translation of FDDQL

The User Agreement (see Appendix 1) and Translation Agreement (see Appendix 2) of English version of FDDQL (see Appendix 3) from MAPI RESEARCH TRUST were obtained by the corresponding author (Prof. Liu Feng-bin) on December 23rd 2008. Meanwhile, permission for the study from the Research Ethics Committees in Guangzhou University of Chinese Medicine was also obtained.

\section{Forward Translations}

Two Chinese translators (A and B) proficiently fluent in English translated the complete English version of FDDQL, including item content, response options and instructions, into Chinese independently (FWT-A and FWT-B). Translator A was a physician and researcher. His work was intended to produce a translation providing a more reliable equivalence from a measurement perspective. Translator B (naive translator) has no medical background. His task was more focused on highlighting ambiguous meanings in the original questionnaire. They produced written reports summarizing all difficulties encountered, choices made and remaining uncertainties.

Synthesis of the Translations

The aim was to come up with one single version which is accepted by most participators. Coordinated by Prof. Liu Feng-bin, two translations (FWT-A and FWT-B) were merged into one single forward translation (FWT-A/B). The agreements and differences, even if they were very tiny, such as one word or punctuation marks, etc., were identified. The agreements were accepted for further processing, conversely, the differences were discussed item by item by the study group and three FD patients in multiwave focus group meetings. If the disagreements were too 
Table 1 The qualitative research procedure for functional digestive disorders quality of life questionnaire (FDDQL) translation and the results

\begin{tabular}{|c|c|c|c|c|c|c|}
\hline \multirow[t]{2}{*}{ Step } & \multicolumn{3}{|l|}{ Comparisons } & \multicolumn{3}{|l|}{ Qualitative research } \\
\hline & Versions & Agreements & Disagreements & Methods & Waves & Participants \\
\hline Synthesis of the translations & FWT-A and FWT-B & 7 items & 36 items & Focus groups & 2 & $\begin{array}{l}\text { The study group } \\
\text { and three patients }\end{array}$ \\
\hline Backward translations & $\begin{array}{l}\text { a) BWT-C and Original FDDQL } \\
\text { b) BWT-D and Original FDDQL }\end{array}$ & $\begin{array}{l}10 \text { items } \\
15 \text { items }\end{array}$ & $\begin{array}{l}33 \text { items } \\
28 \text { items }\end{array}$ & Expert review & 2 & Seven experts \\
\hline Pilot testing & BWT-C/D and patients' advice & 32 items & 11 items & Patients interview & 2 & $\begin{array}{l}\text { The study group } \\
\text { and } 30 \text { patients }\end{array}$ \\
\hline
\end{tabular}

There was no unsolved problem in each step

difficult to resolve, alternative wording was suggested in the provisional forward translation for resolution through the backward translation process.

There were seven fully consistent items (Q17, Q19, Q20, Q31, Q33, Q39, Q40) in this step. The other 36 items had differences more or less. Of those, many were distributed on the synonyms, adjectives, prepositions, punctuations, word order, attributive adjuncts, etc. For example, as for Q2 'have you had to disrupt your daily activities?', the FWT-A described as “您的消化问题会影响日常活动吗?”, and FWT-B as “您的消化问题会扰乱您的日常活动吗?”. The words “影响” and “打扰” were synonyms in Chinese, and “您的” additionally defined “日常活动” in FWT-B. The two translations were highly similar. Two-wave focus groups meetings were performed and no disagreements were too difficult to resolve (see Table 1, the FWT-A, FWT-B and FWT-A/B are available by request).

\section{Backward Translations}

Totally blinded to the original English version of FDDQL, two translators (C and D) with a high level of fluency in English translated the single forward translation (FWT-A/ B) back into English independently (BWT-C and BWT-D). Translator $\mathrm{C}$ was a physician and researcher with the objective to provide equivalency from a more clinical perspective. Translator D (naive translator) has no medical background. His work aimed to detect the more subtle differences in meaning of the original and offer a translation that reflects common Chinese used.

With the help of a translation coordinator, the agreements and differences between backward English translations and the original questionnaire were identified. Then, multi-wave discussions were performed until one single version (BWT-C/ D) accepted by most participants was approved for pilottesting. Challenging phrases, uncertainties and rationale of final decisions were recorded. An expert review (coordinated by Prof. Liu Feng-bin) was conducted to discuss and resolve any ambiguities in each translation version, and then the pilot testing of FDDQL was produced. The results were shown in Table 1. The BWT-C, BWT-D and BWT-C/D are available upon request.

\section{Pilot Testing}

The study group interviewed 30 FD patients with different educational levels individually by using a semi-structured questionnaire. The interview focused on items which are difficult, confusing, offensive and alternative questions. Then, the study group discussed the disagreements, comprehension, interpretability and suggestions for improvement, and the field testing for the Chinese version of FDDQL was produced (see Table 1). All the modified versions are available upon request.

\section{Field Testing}

Field testing was conducted to collect answers to each question for psychometric validation. A total of 327 consecutive adult patients diagnosed with FD were asked to participate in the study, 300 of them completed the survey. Enrolment started in November 2009 and ended in April 2010 among patients who were attended at the In- and OutDepartments of the First Affiliated Hospital of Guangzhou University of Chinese Medicine. All the participators had to complete the Chinese version of FDDQL and demographic questionnaire (which contains age, gender, residence, highest education level, disease duration, and disease subtype) once they were enrolled. The reliability, validity, responsiveness, individual items property with item response theory (IRT) and differential item functioning (DIF) analysis of the Chinese version of FDDQL were then psychometrically tested using the collected questionnaires.

Of these, 100 FD patients were asked to answer the questionnaire for a second time, after an interval of 1 or 2 days, to assess the test-retest reliability of the FDDQL. Also, 100 participants who had not previously received therapy and who were to start therapy were asked to answer 
the questionnaire twice-before replacement therapy, and again 2 weeks after beginning the therapy, to assess the responsiveness of FDDQL. All the patients received the same therapeutic regimen. The 2 -week period was adopted because clinical experience has demonstrated that the patients' health status usually improved significantly with correct interventions in this interval.

In order to assess the criterion validity of FDDQL, the Chronic Gastritis Subscale in Gastroenteric Disease Patient-Reported Outcome Scale (GEDPRO-CG, Chinese Version) would also be completed in the first interview simultaneously by at least 100 FD patients. GEDPRO-CG was a 31-item self-administered instrument to assess the health status of chronic gastritis and FD patients. The 5point Likert scale contains four domains: physical (19 items), psychological (4 items), independent (4 items) and environment (4 items). Each item scored from 1 (best) to 5 (worst), with higher scores indicating worse health status. The previous studies showed it had good reliability, validity, responsiveness and item properties [18]. Furthermore, 110 healthy people were asked to answer FDDQL to assess its discriminant validity, of those, 100 completed the survey.

\section{Data Analysis}

Demographic and clinical variables of the participants were summarized using descriptive analyses. For reliability, the internal consistency reliability, test-retest reliability and split-half reliability were examined. A Cronbach's alpha coefficient of $\geq 0.70$ was considered acceptable for internal consistency. The correlation coefficient of $\geq 0.70$ was considered acceptable for test-retest reliability. The halftests were created by splitting out the odd-numbered items as one half and the even-numbered items as another half. The correlation of scores between the two halves was calculated by using the Spearman-Brown formula. The coefficient of $\geq 0.70$ was considered acceptable for splithalf reliability [19].

Validity, the construct validity, criterion validity and discriminant validity were examined. For construct validity, correlation analysis and confirmatory factor analysis (CFA) were performed to test the hypothesized domain structure. Higher correlation coefficient with its own domain rather than other domains indicates good construct validity. Overall and every domain's model fit statistics were examined in CFA, as well as standardized regression coefficients (factor loadings) for each item. Good model fit is indicated when the Bentler comparative fit index (CFI) is above 0.90. In addition, root mean square error of approximation (RMSEA) should be below 0.05 as an indication of good model fit, or below 0.08 as acceptable model fit [20]. Criterion validity was calculated with Pearson correlation coefficients among all domains of FDDQL and GEDPRO-CG. The correlation values between 0.10 and 0.29 are considered weak, between 0.30 and 0.49 are considered moderate, and between 0.50 and 1.00 are considered strong. Discriminant validity was measured by the between-groups comparison of FD patients and healthy people. Responsiveness was measured by the within-groups comparison of before- and aftertreatment in FD patients.

Item response theory (IRT) was a mathematical modelbased approach used to understand the relationships between individuals' HRQL (trait latent) and their response patterns [21]. In IRT, the number of item parameters to be estimated determines which IRT statistical model will be used. IRT models can be divided into two families: unidimensional and multidimensional. Of those, multidimensional IRT models model response data hypothesized to arise from multiple traits. The FDDQL data were fitted to the partial credit model (PCM). Person separation index (PSI) values of 0.90 or greater indicate excellent property, and individual item fit residual statistics were acceptable when the value ranged from -2.5 to +2.5 . The item fit residual statistics (short for Fit Resid) was analyzed by chi square with Bonferroni correction [22].

Differential item functioning (DIF) of each item was also evaluated. For a certain item, if distributions of the response from different people with the same HRQL (trait latent) were different, then the item was regarded as having DIF. If the item displayed a constant difference between groups through the whole range of HRQL, then the item was considered displaying a uniform DIF. When the differences occurred only at a certain level, the item displayed a non-uniform DIF. Both uniform DIF and non-uniform DIF were checked.

Data description, reliability, validity and responsiveness of FDDQL were analyzed by SPSS 11.0. CFA was conducted by using Lisrel software (version 8.7) [23]. IRT and DIF analysis was performed with the Rasch Unidimensional Measurement Model software 2020 (RUMM) [24]. All statistical tests were two-tailed, and the level of significance was set at $5 \%$.

\section{Results}

Socio-Demographic and Disease Characteristics

A total of $327 \mathrm{FD}$ patients and 110 healthy people were enrolled in the field study. Of those, 27 patients and ten healthy people who didn't complete the survey due to inadequate time were excluded. Finally, 300 FD patients 
Table 2 The socio-demographic and disease characteristics of participators in field testing

\begin{tabular}{|c|c|c|c|c|c|}
\hline Characteristics & $\begin{array}{l}\text { Total patients } \\
(N=300)\end{array}$ & $\begin{array}{l}\text { Test-retest reliability } \\
(N=100)\end{array}$ & $\begin{array}{l}\text { Criterion validity } \\
(N=100)\end{array}$ & $\begin{array}{l}\text { Responsiveness } \\
(N=100)\end{array}$ & $\begin{array}{l}\text { Healthy people }(\%) \\
(N=100)\end{array}$ \\
\hline Ages (years) & $31.83 \pm 27.00$ & $32.75 \pm 27.00$ & $32.81 \pm 28.50$ & $31.37 \pm 27.50$ & $30.48 \pm 26.76$ \\
\hline \multicolumn{6}{|l|}{ Gender } \\
\hline Male & $160(53.3)$ & $52(52.0)$ & $53(53.0)$ & $60(60.0)$ & $51(51.0)$ \\
\hline Female & $140(46.7)$ & $48(48.0)$ & $47(47.0)$ & $40(40.0)$ & $49(49.0)$ \\
\hline \multicolumn{6}{|l|}{ Residence } \\
\hline City or town & $267(89.0)$ & $87(87.0)$ & $87(87.0)$ & $87(87.0)$ & $85(85.0)$ \\
\hline Rural & $33(11.0)$ & $13(13.0)$ & $13(13.0)$ & $13(13.0)$ & $15(15.0)$ \\
\hline \multicolumn{6}{|l|}{ Highest education levels } \\
\hline Less than high education & $79(26.3)$ & $28(28.0)$ & $29(29.0)$ & $27(27.0)$ & $31(31.0)$ \\
\hline High education or above & $221(73.7)$ & $72(72.0)$ & $71(71.0)$ & $73(73.0)$ & $69(69.0)$ \\
\hline Disease duration (weeks) & $6.89 \pm 8.00$ & $6.76 \pm 8.00$ & $6.62 \pm 8.00$ & $6.81 \pm 8.00$ & - \\
\hline \multicolumn{6}{|l|}{ Functional dyspepsia subtype } \\
\hline Postprandial distress syndrome & $178(59.3)$ & $55(55.0)$ & $58(58.0)$ & $60(60.0)$ & - \\
\hline Epigastric pain syndrome & $122(40.7)$ & $45(45.0)$ & $42(42.0)$ & $40(40.0)$ & - \\
\hline
\end{tabular}

Values given as functional dyspepsia patients, n (\%)

and 100 healthy people were engaged in total data analysis. Of those, 100, 100, and 100 patients were included for testretest reliability, criterion validity and responsiveness analysis, respectively. The socio-demographic and disease characteristics of different group participators are shown in Table 2. There is no missing data in item response. The average completion time of FDDQL was $12.45 \pm 3.13 \mathrm{~min}$.

Reliability

Three hundred patients' data were used for internal consistency reliability and split-half reliability analysis, and 100 were used for test-retest reliability analysis. The global Cronbach's $\alpha$ of the Chinese version of FDDQL was 0.932 , and coefficients of eight domains ranged from 0.676 to 0.817 . The global split-half reliability coefficient was 0.823 and coefficients of eight domains ranged from 0.703 to 0.820. As for test-retest reliability, all domains' coefficients were greater than 0.9 except the health perceptions domain $(r=0.738)$ (Table 3$)$.

\section{Validity}

\section{Construct Validity}

Items-domains correlation analysis showed that all items correlated more strongly with their own domains than with other domains (Table 4). CFA analysis showed the CFI of global FDDQL was 0.902 and RMSEA was 0.076, and the CFI values of activities (0.950), anxiety (0.970), diet
Table 3 Scale reliability of Chinese version of functional digestive disorders quality of life questionnaire (FDDQL) (43 items, 8 domains)

\begin{tabular}{|c|c|c|c|}
\hline Domains & $\begin{array}{l}\text { Cronbachs' } \alpha \\
(N=300)\end{array}$ & $\begin{array}{l}\text { Split-half } \\
\text { reliability } \\
\text { coefficient } \\
(N=300)\end{array}$ & $\begin{array}{l}\text { Test-retest } \\
\text { reliability } \\
\text { coefficient } \\
(N=100)\end{array}$ \\
\hline Activities (8 items) & 0.806 & 0.820 & 0.980 \\
\hline Anxiety (5 items) & 0.805 & 0.713 & 0.968 \\
\hline Diet (6 items) & 0.817 & 0.781 & 0.967 \\
\hline Sleep (3 items) & 0.676 & 0.735 & 0.961 \\
\hline Discomfort (9 items) & 0.812 & 0.744 & 0.905 \\
\hline $\begin{array}{l}\text { Health perceptions } \\
\quad(6 \text { items })\end{array}$ & 0.751 & 0.703 & 0.738 \\
\hline $\begin{array}{l}\text { Coping with disease } \\
\text { ( } 3 \text { items) }\end{array}$ & 0.818 & 0.733 & 0.972 \\
\hline $\begin{array}{l}\text { Impact of stress } \\
\text { (3 items) }\end{array}$ & 0.722 & 0.705 & 0.957 \\
\hline Total (43 items) & 0.932 & 0.823 & 0.976 \\
\hline
\end{tabular}

(0.960), sleep (0.965), discomfort (0.910), health perceptions (0.940), coping with disease (0.920) and impact of stress (0.905) domains were all greater than 0.9 (see Fig. 1, and the complete CFA results are available upon request).

\section{Criterion Validity}

The criterion validity of the Chinese version of FDDQL was assessed by the correlations with GEDPRO-CG. It should be noted that higher scores on FDDQL indicate better quality of life, while higher scores on GEDPRO-CG 
Table 4 Items-domains correlation analysis of Chinese version of functional digestive disorders quality of life questionnaire (FDDQL) (43 items, 8 domains, $N=\mathbf{3 0 0}$ )

\begin{tabular}{|c|c|c|c|c|c|c|c|c|c|}
\hline Questions & $\begin{array}{l}\text { Activities } \\
\text { (8 items) }\end{array}$ & $\begin{array}{l}\text { Anxiety } \\
\text { (5 items) }\end{array}$ & $\begin{array}{l}\text { Diet } \\
(6 \text { items })\end{array}$ & $\begin{array}{l}\text { Sleep } \\
\text { (3 items) }\end{array}$ & $\begin{array}{l}\text { Discomfort } \\
\text { (9 items) }\end{array}$ & $\begin{array}{l}\text { Health } \\
\text { perceptions } \\
(6 \text { items })\end{array}$ & $\begin{array}{l}\text { Coping with } \\
\text { disease } \\
\text { (3 items) }\end{array}$ & $\begin{array}{l}\text { Impact of } \\
\text { stress } \\
\text { (3 items) }\end{array}$ & $\begin{array}{l}\text { Total } \\
\text { (43 items) }\end{array}$ \\
\hline Q1 & $-0.565^{* *}$ & $-0.314 * *$ & $-0.290 * *$ & $-0.294 * *$ & $-0.257 * *$ & $-0.302 * *$ & $-0.323 * *$ & $-0.130 *$ & $-0.445^{* *}$ \\
\hline $\mathrm{Q} 2$ & $-0.638 * *$ & $-0.297 * *$ & $-0.452 * *$ & $-0.328 * *$ & $-0.481 * *$ & $-0.328 * *$ & $-0.228 * *$ & $-0.139^{*}$ & $-0.538 * *$ \\
\hline Q3 & $-0.682 * *$ & $-0.383 * *$ & $-0.379 * *$ & $-0.292 * *$ & $-0.335^{* *}$ & $-0.253 * *$ & $-0.114 *$ & $-0.117 *$ & $-0.473 * *$ \\
\hline Q4 & $-0.591 * *$ & $-0.243^{* *}$ & $-0.203 * *$ & $-0.183^{* *}$ & $-0.203^{* *}$ & $-0.280 * *$ & $-0.276^{* *}$ & $-0.304 * *$ & $-0.373^{* *}$ \\
\hline Q5 & $-0.656^{* *}$ & $-0.376^{* *}$ & $-0.297 * *$ & $-0.251 * *$ & $-0.321 * *$ & $-0.301 * *$ & $-0.332 * *$ & $-0.282 * *$ & $-0.489 * *$ \\
\hline Q6 & $-0.654 * *$ & $-0.410^{* *}$ & $-0.322 * *$ & $-0.315^{* *}$ & $-0.321 * *$ & $-0.258^{* *}$ & $-0.283^{* *}$ & $-0.204 * *$ & $-0.483 * *$ \\
\hline Q7 & $-0.690 * *$ & $-0.373^{* *}$ & $-0.353 * *$ & $-0.260 * *$ & $-0.325^{* *}$ & $-0.324 * *$ & $-0.281 * *$ & $-0.226^{* *}$ & $-0.500 * *$ \\
\hline Q8 & $-0.746^{* *}$ & $-0.487 * *$ & $-0.415^{* *}$ & $-0.355^{* *}$ & $-0.391 * *$ & $-0.374 * *$ & $-0.337 * *$ & $-0.240 * *$ & $-0.597 * *$ \\
\hline Q9 & $-0.486 * *$ & $-0.785^{* *}$ & $-0.447 * *$ & $-0.310 * *$ & $-0.392 * *$ & $-0.331 * *$ & $-0.339 * *$ & $-0.326^{* *}$ & $-0.597 * *$ \\
\hline Q10 & $-0.303^{* *}$ & $-0.728 * *$ & $-0.396 * *$ & $-0.348 * *$ & $-0.324 * *$ & $-0.296^{* *}$ & $-0.258 * *$ & $-0.184 * *$ & $-0.502 * *$ \\
\hline Q11 & $-0.441 * *$ & $-0.772 * *$ & $-0.421 * *$ & $-0.425^{* *}$ & $-0.400 * *$ & $-0.382 * *$ & $-0.341 * *$ & $-0.261 * *$ & $-0.606^{* *}$ \\
\hline Q12 & $-0.399 * *$ & $-0.736^{* *}$ & $-0.508 * *$ & $-0.374 * *$ & $-0.373 * *$ & $-0.395 * *$ & $-0.303 * *$ & $-0.273^{* *}$ & $-0.582 * *$ \\
\hline Q13 & $-0.438 * *$ & $-0.732 * *$ & $-0.458 * *$ & $-0.421 * *$ & $-0.396^{* *}$ & $-0.448 * *$ & $-0.382 * *$ & $-0.283^{* *}$ & $-0.617 * *$ \\
\hline Q14 & $-0.406^{* *}$ & $-0.548 * *$ & $-0.649 * *$ & $-0.316^{* *}$ & $-0.393^{* *}$ & $-0.175^{* *}$ & $-0.260 * *$ & $-0.135^{*}$ & $-0.528 * *$ \\
\hline Q15 & $-0.381 * *$ & $-0.526^{* *}$ & $-0.781 * *$ & $-0.336^{* *}$ & $-0.391 * *$ & $-0.321 * *$ & $-0.277 * *$ & $-0.248^{* *}$ & $-0.583 * *$ \\
\hline Q16 & $-0.416^{* *}$ & $-0.347 * *$ & $-0.712 * *$ & $-0.296 * *$ & $-0.419 * *$ & $-0.240 * *$ & $-0.225^{* *}$ & $-0.141^{*}$ & $-0.517 * *$ \\
\hline Q17 & $-0.287 * *$ & $-0.353 * *$ & $-0.742 * *$ & $-0.295 * *$ & $-0.295^{* *}$ & $-0.285^{* *}$ & $-0.189 * *$ & -0.111 & $-0.472 * *$ \\
\hline Q18 & $-0.349 * *$ & $-0.358 * *$ & $-0.782 * *$ & $-0.316^{* *}$ & $-0.398 * *$ & $-0.404 * *$ & $-0.234 * *$ & $-0.190 * *$ & $-0.556^{* *}$ \\
\hline Q19 & $-0.435^{* *}$ & $-0.490 * *$ & $-0.673 * *$ & $-0.424 * *$ & $-0.408 * *$ & $-0.371 * *$ & $-0.300 * *$ & $-0.183^{* *}$ & $-0.593 * *$ \\
\hline Q20 & $-0.351 * *$ & $-0.287 * *$ & $-0.259 * *$ & $-0.720 * *$ & $-0.394 * *$ & $-0.331 * *$ & $-0.338 * *$ & $-0.135^{*}$ & $-0.471 * *$ \\
\hline Q21 & $-0.290 * *$ & $-0.416^{* *}$ & $-0.406^{* *}$ & $-0.811 * *$ & $-0.366^{* *}$ & $-0.341 * *$ & $-0.312 * *$ & $-0.175^{* *}$ & $-0.532 * *$ \\
\hline Q22 & $-0.376^{* *}$ & $-0.480 * *$ & $-0.397 * *$ & $-0.810 * *$ & $-0.411 * *$ & $-0.372 * *$ & $-0.351 * *$ & $-0.171 * *$ & $-0.583 * *$ \\
\hline Q23 & $-0.410 * *$ & $-0.415^{* *}$ & $-0.530 * *$ & $-0.284 * *$ & $-0.666 * *$ & $-0.279 * *$ & $-0.263^{* *}$ & -0.071 & $-0.564 * *$ \\
\hline Q24 & $-0.274 * *$ & $-0.360 * *$ & $-0.375^{* *}$ & $-0.340 * *$ & $-0.679 * *$ & $-0.289 * *$ & $-0.281 * *$ & $-0.191 * *$ & $-0.520 * *$ \\
\hline Q25 & $-0.280 * *$ & $-0.355^{* *}$ & $-0.322 * *$ & $-0.343 * *$ & $-0.591 * *$ & $-0.311 * *$ & $-0.305^{* *}$ & $-0.172 * *$ & $-0.490 * *$ \\
\hline Q26 & $-0.310 * *$ & $-0.327 * *$ & $-0.304 * *$ & $-0.383^{* *}$ & $-0.713 * *$ & $-0.243 * *$ & $-0.283 * *$ & $-0.157 * *$ & $-0.512 * *$ \\
\hline Q27 & $-0.292 * *$ & $-0.355^{* *}$ & $-0.360 * *$ & $-0.330 * *$ & $-0.601 * *$ & $-0.215^{* *}$ & $-0.296 * *$ & $-0.234 * *$ & $-0.480 * *$ \\
\hline Q28 & $-0.328 * *$ & $-0.291 * *$ & $-0.253 * *$ & $-0.314 * *$ & $-0.652 * *$ & $-0.204 * *$ & $-0.224 * *$ & $-0.136^{*}$ & $-0.453 * *$ \\
\hline Q29 & $-0.268 * *$ & $-0.359 * *$ & $-0.346^{* *}$ & $-0.388 * *$ & $-0.644 * *$ & $-0.191 * *$ & $-0.278 * *$ & $-0.176^{* *}$ & $-0.488 * *$ \\
\hline Q30 & $-0.359 * *$ & $-0.213 * *$ & $-0.255^{* *}$ & $-0.223 * *$ & $-0.581 * *$ & $-0.390 * *$ & $-0.326^{* *}$ & $-0.149 * *$ & $-0.452 * *$ \\
\hline Q31 & $-0.347 * *$ & $-0.214 * *$ & $-0.283 * *$ & $-0.266^{* *}$ & $-0.583 * *$ & $-0.379 * *$ & $-0.322 * *$ & $-0.132 *$ & $-0.458 * *$ \\
\hline Q32 & $-0.508 * *$ & $-0.402 * *$ & $-0.426^{* *}$ & $-0.291 * *$ & $-0.456 * *$ & $-0.685^{* *}$ & $-0.484 * *$ & $-0.384 * *$ & $-0.644 * *$ \\
\hline Q33 & $-0.330 * *$ & $-0.391 * *$ & $-0.305^{* *}$ & $-0.379 * *$ & $-0.359 * *$ & $-0.722 * *$ & $-0.497 * *$ & $-0.358 * *$ & $-0.579 * *$ \\
\hline Q34 & $-0.181 * *$ & $-0.287 * *$ & $-0.292 * *$ & $-0.341 * *$ & $-0.247 * *$ & $-0.659 * *$ & $-0.370 * *$ & $-0.318 * *$ & $-0.465 * *$ \\
\hline Q35 & $-0.282 * *$ & $-0.238^{* *}$ & -0.103 & $-0.200 * *$ & $-0.220 * *$ & $-0.602 * *$ & $-0.419 * *$ & $-0.225^{* *}$ & $-0.411 * *$ \\
\hline Q36 & $-0.296 * *$ & $-0.377 * *$ & $-0.342 * *$ & $-0.291 * *$ & $-0.304 * *$ & $-0.704 * *$ & $-0.309 * *$ & $-0.264 * *$ & $-0.521 * *$ \\
\hline Q37 & $-0.251 * *$ & $-0.279 * *$ & $-0.173 * *$ & $-0.286 * *$ & $-0.176^{* *}$ & $-0.634 * *$ & $-0.326 * *$ & $-0.209 * *$ & $-0.413 * *$ \\
\hline Q38 & $-0.355^{* *}$ & $-0.339 * *$ & $-0.264 * *$ & $-0.369 * *$ & $-0.377 * *$ & $-0.545^{* *}$ & $-0.868 * *$ & $-0.532 * *$ & $-0.597 * *$ \\
\hline Q39 & $-0.370 * *$ & $-0.362 * *$ & $-0.282 * *$ & $-0.326^{* *}$ & $-0.439 * *$ & $-0.483 * *$ & $-0.844 * *$ & $-0.450 * *$ & $-0.592 * *$ \\
\hline Q40 & $-0.351 * *$ & $-0.410^{* *}$ & $-0.322 * *$ & $-0.401 * *$ & $-0.355^{* *}$ & $-0.506^{* *}$ & $-0.857 * *$ & $-0.441 * *$ & $-0.601 * *$ \\
\hline Q41 & $-0.274 * *$ & $-0.246^{* *}$ & $-0.187 * *$ & $-0.171 * *$ & $-0.225^{* *}$ & $-0.378^{* *}$ & $-0.437 * *$ & $-0.798 * *$ & $-0.380 * *$ \\
\hline Q42 & $-0.281 * *$ & $-0.266^{* *}$ & $-0.223 * *$ & -0.093 & $-0.201 * *$ & $-0.282 * *$ & $-0.383 * *$ & $-0.800 * *$ & $-0.360 * *$ \\
\hline Q43 & $-0.218 * *$ & $-0.332 * *$ & $-0.154 * *$ & $-0.219 * *$ & $-0.176^{* *}$ & $-0.386 * *$ & $-0.505 * *$ & $-0.814 * *$ & $-0.410^{* *}$ \\
\hline
\end{tabular}

$* p<0.05 ; * * p<0.01$ 
Fig. 1 Confirmatory factor analysis of global functional digestive disorders quality of life questionnaire (FDDQL)

(43 items, question 1-43)

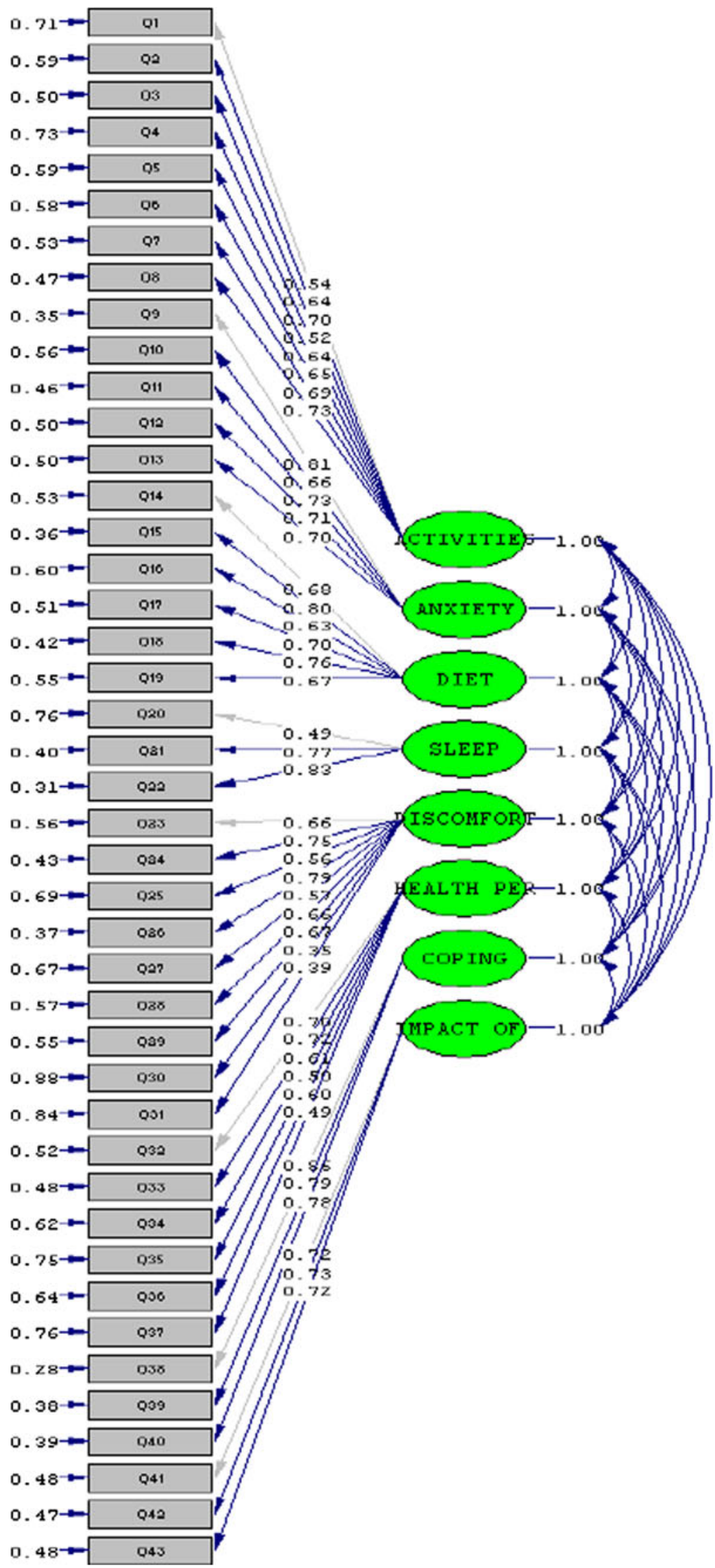


Table 5 Criterion validity analysis between the Chinese version of the functional digestive disorders quality of life questionnaire (FDDQL) and chronic gastritis subscale in the gastroenteric disease patient-reported outcome scale (GEDPRO-CG, Chinese version, 31 items, 4 domains) $(N=\mathbf{1 0 0})$

\begin{tabular}{|c|c|c|c|c|}
\hline \multirow[t]{2}{*}{ Domains } & \multicolumn{4}{|c|}{ Chronic gastritis subscale in the gastroenteric disease patient-reported outcome scale (GEDPRO-CG) } \\
\hline & Physical (19 items) & Psychological (4 items) & Independent (4 items) & Environmental (4 items) \\
\hline \multicolumn{5}{|l|}{$F D D Q L$} \\
\hline Activities (8 items) & $-0.60^{\dagger}$ & $-0.73^{\dagger}$ & $-0.38^{\dagger}$ & $-0.43^{\dagger}$ \\
\hline Anxiety (5 items) & $-0.49^{\dagger}$ & $-0.66^{\dagger}$ & $-0.29^{\dagger}$ & $-0.47^{\dagger}$ \\
\hline Diet (6 items) & $-0.46^{\dagger}$ & $-0.50^{\dagger}$ & -0.17 & $-0.26^{\dagger}$ \\
\hline Sleep (3 items) & $-0.48^{\dagger}$ & $-0.39^{\dagger}$ & $-0.37^{\dagger}$ & $-0.39^{\dagger}$ \\
\hline Discomfort (9 items) & $-0.46^{\dagger}$ & $-0.55^{\dagger}$ & $-0.33^{\dagger}$ & $-0.38^{\dagger}$ \\
\hline Health perceptions (6 items) & $-0.35^{\dagger}$ & $-0.37^{\dagger}$ & -0.16 & $-0.24^{\dagger}$ \\
\hline Coping with disease ( 3 items) & $-0.40^{\dagger}$ & $-0.46^{\dagger}$ & $-0.30^{\dagger}$ & $-0.33^{\dagger}$ \\
\hline Impact of stress (3 items) & $-0.24^{\dagger}$ & -0.13 & -0.16 & -0.14 \\
\hline Total (43 items) & $-0.65^{\dagger}$ & $-0.75^{\dagger}$ & $-0.39^{\dagger}$ & $-0.49^{\dagger}$ \\
\hline
\end{tabular}

* Higher scores on the FDDQL indicate better quality of life, while higher scores on the GEDPRO-CG indicate worse health status. Consequently, strong negative correlations indicate good criterion validity

$\dagger p<0.05$

Table 6 Discriminant validity analysis of the Chinese version of the functional digestive disorders quality of life questionnaire (FDDQL) (43 items, 8 domains) with functional dyspepsia patients and healthy people $(N=\mathbf{1 0 0})$

\begin{tabular}{|c|c|c|c|c|}
\hline \multirow[t]{2}{*}{ Domains } & \multicolumn{2}{|l|}{ Scores } & \multirow[t]{2}{*}{$t$} & \multirow[t]{2}{*}{$p$} \\
\hline & $\begin{array}{l}\text { Functional } \\
\text { dyspepsia } \\
\text { patients }\end{array}$ & $\begin{array}{l}\text { Healthy } \\
\text { people }\end{array}$ & & \\
\hline Activities & $75.4 \pm 11.7$ & $93.6 \pm 3.2$ & 24.21 & $<0.001$ \\
\hline Anxiety & $58.0 \pm 15.7$ & $91.6 \pm 4.9$ & 32.63 & $<0.001$ \\
\hline Diet & $61.4 \pm 16.2$ & $86.8 \pm 5.9$ & 22.91 & $<0.001$ \\
\hline Sleep & $66.5 \pm 17.8$ & $90.4 \pm 8.2$ & 18.21 & $<0.001$ \\
\hline Discomfort & $63.3 \pm 13.9$ & $90.7 \pm 4.0$ & 30.41 & $<0.001$ \\
\hline Health perceptions & $46.1 \pm 17.6$ & $91.3 \pm 5.2$ & 39.61 & $<0.001$ \\
\hline Coping with disease & $50.9 \pm 22.5$ & $91.4 \pm 7.4$ & 27.04 & $<0.001$ \\
\hline Impact of stress & $45.9 \pm 19.8$ & $91.7 \pm 6.0$ & 35.53 & $<0.001$ \\
\hline Total & $60.8 \pm 11.7$ & $91.0 \pm 2.3$ & 41.64 & $<0.001$ \\
\hline
\end{tabular}

indicate worse health status. Consequently, strong negative correlations indicate good criterion validity. Almost all the Spearman rank correlation coefficients $(86.11 \%)$ were statistically significant $(p<0.05)$. The two most strongly correlated FDDQL with GEDPRO-CG were those for activities and psychological domains $(r=-0.73)$, and the two weakest correlated domains were impact of stress in FDDQL and psychological in GEDPRO-CG $(r=-0.13)$ (Table 5).

\section{Discriminant Validity}

The discriminant validity was assessed by comparing FDDQL scores between FD patients and healthy people. There were no significant differences on the age $(p=0.766)$, gender $(p=0.686)$, residence $(p=0.286)$ and highest education levels $(n=0.365)$ between the FD patients and healthy people. Scores for each domain ranged from 0 (poor quality of life) to 100 (good quality of life), and the healthy people have higher scale mean scores. All the domains' differences between FD patients and healthy people were significant $(p<0.001)$ (Table 6).

\section{Responsiveness}

The mean change in FDDQL domain scores from baseline to 2 weeks indicates statistically significant changes $(p<0.05)$ (Table 7). Of those, the SLEEP domain demonstrated the greatest change in patient-perceived quality of life, with mean change scores of $10.42 \pm 1.19(p<0.001)$. The effect 
Table 7 Responsiveness analysis of the Chinese version of the functional digestive disorders quality of life questionnaire (FDDQL) (43 items, 8 domains) $(N=\mathbf{1 0 0})$

SEM standardized response means, $E S$ effect sizes

\begin{tabular}{lllrrr}
\hline Domains & $x \pm \mathrm{s}$ & \multicolumn{1}{l}{$t$} & \multicolumn{1}{l}{ SEM } & \multicolumn{1}{l}{ ES } \\
\hline Activities & $6.66 \pm 0.56$ & 11.973 & $<0.001$ & 1.189 & 0.569 \\
Anxiety & $9.95 \pm 0.89$ & 11.192 & $<0.001$ & 1.118 & 0.634 \\
Diet & $-2.67 \pm 0.75$ & -3.565 & 0.001 & 0.356 & 0.165 \\
Sleep & $10.42 \pm 1.19$ & 8.778 & $<0.001$ & 0.876 & 0.585 \\
Discomfort & $8.22 \pm 0.88$ & 9.314 & $<0.001$ & 0.934 & 0.591 \\
Health perceptions & $2.33 \pm 1.12$ & 2.076 & 0.041 & 0.208 & 0.132 \\
Coping with disease & $7.83 \pm 1.48$ & 5.298 & $<0.001$ & 0.529 & 0.348 \\
Impact of stress & $4.25 \pm 1.37$ & 3.094 & 0.003 & 0.310 & 0.215 \\
Total & $5.74 \pm 0.55$ & 10.39 & $<0.001$ & 1.044 & 0.491 \\
\hline
\end{tabular}

sizes (ES) of FDDQL from baseline to 2 weeks was 0.49 and the standardized response mean (SRM) was 1.04.

Item Response Theory and Differential Item

Functioning Analysis

All the items fitted for the IRT analysis and partial credit model (PCM) were used. The PSI was equal to 0.920. The threshold estimator of the items showed in the third column of Table 8 was normally distributed with a mean of 0 and $\mathrm{SD}$ of 1.27. The threshold estimator of item 31 was minimum $(\mathrm{Q} 31=-2.04)$, which meant that "have you been satisfied with your digestion?" was the most easy item for FD patients to get a high score. The threshold estimator of item 3 was maximum $(\mathrm{Q} 3=2.30)$, which meant that FD patients had the greatest difficulty in getting a high score for "have you had any difficulties carrying out your leisure activities". The residuals of each item were between -2.5 and 2.5, with no statistical significance, which also meant the model was consistent with the theoretical model (the fourth and fifth column of Table 7). All the factor loadings of items were statistically significant, and almost all of them were greater than 0.4 (see the second column of Table 8). The structural plot of observed variables and latent variables are shown in Fig. 1. As we all know, DIF contains uniform and non-uniform DIF. The analysis in this study found that the items of the Chinese version of FDDQL had neither uniform nor non-uniform DIF in different genders and age groups $(\leq 30,31-44, \geq 45$ years $)$.

\section{Discussion}

The abdominal pain or discomfort caused by functional dyspepsia (FD) results in interference of daily activities and brings considerable anxiety and depression to patients. The assessment of HRQOL of FD patients is essential. The FDDQL scale was developed by a collaboration of French,
English and German researchers, and has been widely used in many countries. To date, it has already been translated into English (for Canada, UK, USA), French (for Canada), German (for Germany), Hungarian, Italian (for Italy), Russian (for Russia) and Spanish (for Spain). Due to the growing number of FD patients, it has become an absolute necessity to develop or introduce a scale with adequate psychometric characteristics for the quality of life measurement. So, the development of the Chinese version of the FDDQL was necessary. Self-evaluation of the QOL by the patients might provide insight into appropriate measures for patient treatment and care. Also, this study describes a translation and validation process of FDDQL to Chinese (see Appendices 4 and 5).

\section{Psychometric Properties}

The Chinese version of the FDDQL has good reliability. Internal reliability analysis showed the Cronbachs' $\alpha$ of global FDDQL was excellent (0.932), with each domain greater than 0.7 except sleep (0.676). This may be caused by the fewer number of items ( 3 items). The results were consistent with previous studies in which Cronbachs' $\alpha$ ranged from 0.69 to 0.89 [3]. The split-half reliability coefficient of the Chinese version of FDDQL was 0.823 with each domain greater than 0.7. As for test-retest reliability analysis, all the coefficients of FDDQL domains were greater than 0.9 except coping with disease (0.738).

In validity analysis, the correlation coefficients of all the items with their own domains were significantly higher than the others. In addition, the confirmatory factor analysis (CFA) model was used to reflect the relationship between latent variable and items. The CFA showed the determination coefficient was 0.42 which means the structure model explained $42 \%$ variation of the dependent variable. CFI of the overall model was 0.902 and RMSEA was 0.076 , which indicated the model was consistent with the theoretical construct. As for criterion validity, it was 
Table 8 Confirmatory factor analysis, item response theory and differential item functioning analysis of the Chinese version of the functional digestive disorders quality of life questionnaire (FDDQL) (43 items, 8 domains) $(N=\mathbf{3 0 0})$

\begin{tabular}{|c|c|c|c|c|c|c|}
\hline \multirow[t]{2}{*}{ Questions } & \multirow[t]{2}{*}{ Factor loading of CFA } & \multirow[t]{2}{*}{ Threshold } & \multirow[t]{2}{*}{ Fit Resid } & \multirow[t]{2}{*}{$p$ value } & \multicolumn{2}{|c|}{$\mathrm{DIF}^{\mathrm{a}}$} \\
\hline & & & & & Age & Gender \\
\hline Q1 & 0.54 & 1.45 & 0.66 & 0.723 & - & - \\
\hline Q2 & 0.64 & 1.10 & 0.44 & 0.769 & - & - \\
\hline Q3 & 0.70 & 2.30 & 0.92 & 0.541 & - & - \\
\hline Q4 & 0.52 & 1.96 & 0.74 & 0.491 & - & - \\
\hline Q5 & 0.64 & 1.85 & 0.35 & 0.249 & - & - \\
\hline Q6 & 0.65 & 1.77 & 0.24 & 0.329 & - & - \\
\hline Q7 & 0.69 & 1.99 & 0.19 & 0.811 & - & - \\
\hline Q8 & 0.73 & 1.33 & -0.12 & 0.998 & - & - \\
\hline Q9 & 0.81 & -1.55 & -0.81 & 0.384 & - & - \\
\hline Q10 & 0.66 & -0.24 & 0.26 & 0.514 & - & - \\
\hline Q11 & 0.73 & 1.03 & -0.53 & 0.462 & - & - \\
\hline Q12 & 0.71 & -1.00 & -0.80 & 0.040 & - & - \\
\hline Q13 & 0.70 & -0.60 & -1.00 & 0.034 & - & - \\
\hline Q14 & 0.68 & -0.73 & 0.08 & 0.086 & - & - \\
\hline Q15 & 0.80 & -0.72 & -0.78 & 0.359 & - & - \\
\hline Q16 & 0.63 & 0.24 & 1.98 & 0.170 & - & - \\
\hline Q17 & 0.70 & -0.85 & 1.43 & 0.151 & - & - \\
\hline Q18 & 0.76 & -1.03 & 0.22 & 0.504 & - & - \\
\hline Q19 & 0.67 & 1.42 & -0.10 & 0.147 & - & - \\
\hline Q20 & 0.49 & -0.18 & -0.77 & 0.367 & - & - \\
\hline Q21 & 0.77 & -0.38 & 0.13 & 0.409 & - & - \\
\hline Q22 & 0.83 & 0.70 & -0.81 & 0.255 & - & - \\
\hline Q23 & 0.66 & 1.32 & 0.00 & 0.070 & - & - \\
\hline Q24 & 0.75 & -0.48 & 0.24 & 0.961 & - & - \\
\hline Q25 & 0.56 & 1.45 & -0.26 & 0.423 & - & - \\
\hline Q26 & 0.79 & -0.78 & 1.14 & 0.355 & - & - \\
\hline Q27 & 0.57 & 1.35 & 1.48 & 0.452 & - & - \\
\hline Q28 & 0.66 & 0.99 & 0.92 & 0.182 & - & - \\
\hline Q29 & 0.67 & 1.34 & 1.30 & 0.393 & - & - \\
\hline Q30 & 0.35 & -1.79 & -1.44 & 0.155 & - & - \\
\hline Q31 & 0.39 & -2.04 & -0.23 & 0.733 & - & - \\
\hline Q32 & 0.70 & -1.18 & -1.29 & 0.130 & - & - \\
\hline Q33 & 0.72 & -1.32 & -0.33 & 0.131 & - & - \\
\hline Q34 & 0.61 & -1.65 & -0.18 & 0.692 & - & - \\
\hline Q35 & 0.50 & -0.71 & 1.18 & 0.008 & - & - \\
\hline Q36 & 0.60 & -1.24 & 0.81 & 0.294 & - & - \\
\hline Q37 & 0.49 & -0.06 & 2.20 & 0.212 & - & - \\
\hline Q38 & 0.65 & -0.81 & 0.27 & 0.349 & - & - \\
\hline Q39 & 0.79 & -0.68 & -0.07 & 0.263 & - & - \\
\hline Q40 & 0.78 & -0.92 & 0.19 & 0.043 & - & - \\
\hline Q41 & 0.72 & 0.83 & -0.23 & 0.152 & - & - \\
\hline Q42 & 0.73 & -1.89 & 0.37 & 0.425 & - & - \\
\hline Q43 & 0.72 & -1.60 & 0.62 & 0.041 & - & - \\
\hline
\end{tabular}


mainly supported by the pattern of correlation between FDDQL and GEDPRO-CG. The GEDPRO-CG scale was developed in standard procedure which contains physical, psychological, independent and environment domains. The physiology and psychology domains of FDDQL had significant high correlation coefficients with the physical and psychological domains of GEDPRO-CG, in contrast to independent and environmental domains of GEDPRO-CG. This was consistent with the original research [3]. Also, the discriminant capacity of the FDDQL questionnaire was excellent because the patients reported significantly lower scores than healthy people.

The responsiveness of FDDQL was also confirmed. After FD patients received treatments, their symptoms and psychological status were improved, and almost all domain scores increased significantly. The result was similar with the previous study in which people had significantly increased scores in most FDDQL domains after 7 days intervention [25].

The Person separation index (PSI) of FDDQL was 0.920. The threshold estimator of items was normally distributed with a mean of 0 and SD of 1.27. The residuals of items were between -2.5 and 2.5 , with no statistical significance. All the items were invariant (no item has uniform or non-uniform DIF) in different genders and age groups $(\leq 30,31-44, \geq 45$ years old). This means FD patients in different genders and age groups respond similarly when they suffer from similar severity disease.

\section{Strengths and Limitations}

The main strength of this study is that the questionnaire that was psychometric evaluated with internal consistency reliability, test-retest reliability, split-half reliability, construct validity, criterion validity, discriminant validity, responsiveness, confirmatory factor analysis, item response theory and differential item functioning analysis. The assessment aspects were comprehensive and all the results indicated the Chinese version of FDDQL has good properties. The other strength is that the questionnaire was translated with a rigorous procedure, which includes study group establishment, permissions acquisition, forward translations, synthesis of the translations, backward translations, pilot testing and field testing. The comprehensive psychometric evaluation methods and rigorous translation procedure ensured the Chinese version of FDDQL was scientific and convincing.

The main limitation of the study is that the irritable bowel syndrome (IBS) patients, another intended population for FDDQL, were not included; however, further studies with IBS patients were in progress.

\section{Conclusion}

The Chinese version (in Mandarin) of functional digestive disorders quality of life questionnaire (Chi-FDDQL) was translated according to the standard process, including specifically forward-translation, backward-translation, pilot testing and field testing. The survey data indicate ChiFDDQL has good reliability, validity, responsiveness and other psychometric characteristics with item response theory and different item function analysis. We recommend that Chi-FDDQL can be applied to measure the health status of Chinese FD patients.

Acknowledgments We would like to express our gratitude to Nelson Xie (University of Sydney, Australia) and Bobby Wong (USA) for their assistance in revising this manuscript critically. This work has been supported by the National Natural Science Foundation of China (No. 81073163).

\section{Conflict of interest None.}

Open Access This article is distributed under the terms of the Creative Commons Attribution Noncommercial License which permits any noncommercial use, distribution, and reproduction in any medium, provided the original author(s) and the source are credited. 
Appendix 1: The User-Agreement of the Functional

Digestive Disorders Quality of Life Questionnaire

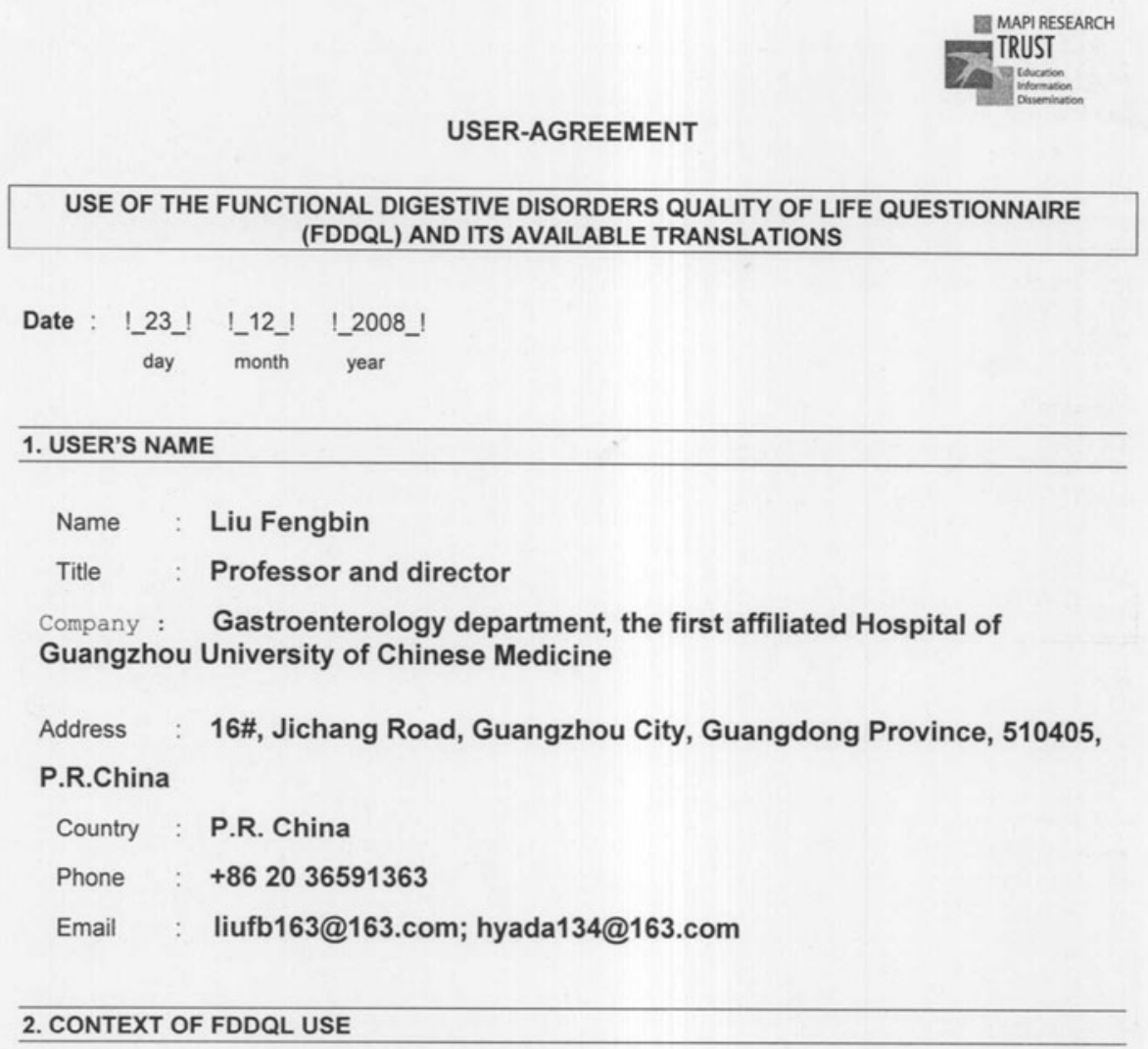

1. Individual clinical practice

Expected duration of use: Indefinite $\square$ or Number of years

2. Research study $\square$

- Title: Cultural adaptation and application of the FDD-QOL in China: a diseasespecific quality-of-life questionnaire

- Disease or disorder.___ Disorder

- Type of research: clinical trial $\square 1$ economic $\square 2$ quality of life $\square 3 \quad$ epidemiologic $\square 4$

- Quality of Life as primary end point: yes $\nabla 1 \quad$ no $\square 2$

- Design: comparative - parallel group comparative - cross-over

non comparative with follow-up or cohort follow-up cross-sectional

Other (please specify)

$\square 4$

$\square 5$

- Number of expected patients (total):

- Number of administrations of the questionnaire per patient:

2

- Length of the follow-up (if any) for each patient:

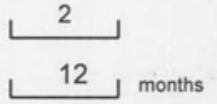

- Planned study date

start $\lcm{12 / 2008}$

end $10 / 2010$

fddql_useragreement.doc

month/vear

month/vear 


\section{STUDY FINANCING}

Not funded academic research, medical practice

Projects not explicitly funded, but funding comes from overall departmental funds or from the University or individual funds.

Funded academic research

Projects receiving funding from commerce, government, EU or registered charity. Funded academic research-sponsored by industry fits the "commercial study" category.

Commercial study

Commercial studies (industry, CRO, any for-profit companies)

$\mathrm{CH}$

intomacion

Granting / Sponsoring from (if any) (name of the governmental/foundation/company or other funding/sponsoring source ): NONE......

\section{TRANSLATIONS}

Please indicate in which language(s) and for which country(ies) the FDDQL is needed:

\begin{tabular}{|l|l|l|l|l|l|}
\hline Language: & $\begin{array}{c}\text { For use in the } \\
\text { following country }\end{array}$ & Language: & $\begin{array}{c}\text { For use in the } \\
\text { following country }\end{array}$ & Language: & $\begin{array}{c}\text { For use in the } \\
\text { following country }\end{array}$ \\
\hline Chinese & China & & & & \\
\hline & & & & & \\
\hline & & & & & \\
\hline & & & & & \\
\hline & & & & & \\
\hline & & & & & \\
\hline
\end{tabular}

Note: The FDDQL translation(s) may not be available in the country required.

Please check availability and status of translations with Mapi Research Trust.

If not available in the language(s) required, a Linguistic Validation must be undergone. 


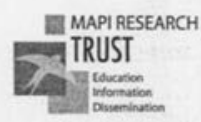

Mapi Research Trust, on behalf of the copyright owners of the FDDQL, Olivier Chassany, Parke Davis, France, and Mapi Values, France, grants "User" the right to use and reproduce the FDDQL in the countries listed in section 4 subject to the following terms, conditions, and only upon signature of this agreement by the "User":

\section{1. "User"'s Obligations}

\subsection{No modification}

"User" shall not modify, abridge, condense, adapt, recast or transform the FDDQL in any manner or form, including but not limited to any minor or significant change in wordings or organization in FDDQL without the prior written agreement of Olivier Chassany, Parke Davis, France, and Mapi Values, France, copyright owners of the FDDQL.

\subsection{No translation}

"User" shall not translate FDDQL without the prior written agreement of Mapi Research Trust (a Translation Agreement shall be completed).

\subsection{No reproduction}

"User" shall not reproduce the FDDQL except for the limited purpose of generating sufficient copies for use in the clinical investigations stated hereunder and shall in no event distribute copies of the FDDQL to third parties that are outside the scope of the defined study by sale, rental, lease, lending, or any others means.

\subsection{Publication}

In case of any kind of publication or presentation mentioning use of the FDDQL, "User" shall cite the main publication reference(s):

- CHASSANY, O., MARQUIS, P., SCHERRER, B., READ, N. W., FINGER, T., BERGMANN, J. F., FRAITAG, B., GENEVE, J., and CAULIN, C. Validation of a Specific Quality of Life Questionnaire for Functional Digestive Disorders. Gut 44(4):527-533, 1999 in reference section of his/her paper.

- The authors of the FDDQL request to be acknowledged in any communication including publication in which the questionnaire is used, as follows: "The Quality of Life study described in this paper was carried out using the Functional Digestive Disorders Quality of Life (FDDQL) questionnaire, jointly developed by Recherches sur l'Evaluation en Santé, Paris, France; Mapi Values, Lyon, France; and Parke Davis, France."

\section{Fees}

\subsection{Royalty Fee}

The use of the FDDQL by profit-making companies is subject to a fee of 8.000 Euros (excluding VAT) payable to Recherches sur l'Evaluation en Santé, to support the continued development of the instrument.

\subsection{Processing fees (Mapi Research Trust)}

The use of the FDDQL in commercial studies involving "for-profit" organizations is subject to a distribution fee payable to Mapi Research Trust, of an amount of 400 (four hundred) Euro per study plus an additional 50 (fifty) Euro per language version requested. 
The use of the FDDQL in funded academic research is subject to a distribution fee payable to Mapi Research Trust, of an amount of 250 (two hundred and fifty) Euro per study plus an additional 20 (twenty) Euro per language version requested.

The use of the FDDQL in non funded academic research and clinical practice is free of charge.

\subsection{Invoicing}

As soon as execution of this agreement, Mapi Research Trust shall promptly provide "User" with a definitive invoice, and "User" shall pay such an invoice on reception.

\section{Copyright}

It is understood that Olivier Chassany, Parke Davis, France, and Mapi Values, France, the copyright owners of the FDDQL, own the copyright of the FDDQL and all its translations (past, on-going and future).

To avoid any copyright infringement, a copyright notice shall be included on the original Questionnaire and all its translations as follows: FDDQLC 1999 Olivier Chassany, Parke Davis, France, and Mapi Values, France, All rights reserved.

If, at any time during the term of this agreement, "User" learns of any infringement by a third party of any Intellectual Property Rights in connection with the FDDQL "User" shall promptly notify Mapi Research Trust. Mapi Research Trust shall notify such infringement to Olivier Chassany, Parke Davis, France, and Mapi Values, France who will decide whether to institute proceedings against the infringing party.

\section{Confidentiality}

All and any information related to the FDDQL including but not limited to the following: information concerning clinical investigations, creations, systems, materials, software, data and know-how; translations, improvements ideas, specifications, documents, records, notebooks, drawings, and any repositories or representation of such information, whether oral or in writing or software stored, are herein referred to as confidential information.

In consideration of the disclosure of any such confidential information to the other, each party agrees to hold such confidential information in confidence and not divulge it, in whole or in part, to any third party except for the purpose specified in this agreement.

\section{Questionnaire data}

All data, results and reports obtained by, or prepared in connection with the FDDQL shall remain the User's property.

\section{Use of name}

It is agreed that Mapi Research Trust shall not disclose, whether by the public press or otherwise, the name of "User's Company name", to any third party to this agreement except to Olivier Chassany, Parke Davis, France, and Mapi Values, France, the copyright owners of the FDDQL.

\section{Copy to the author}

It is understood that a copy of this User Agreement may be provided to Olivier Chassany, Parke Davis, France, and Mapi Values, France.

\section{Liability}

\section{$\underline{8.1 \text { In case of breach of contract }}$}




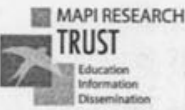

In the event of total or partial breach by Mapi Research Trust of any of its obligations hereunder, Mapi Research Trust's liability shall be limited to the direct loss or damage (excluding loss of profit and operating losses) suffered by "User" as a result of such breach and shall not include any other damages and particular consequential damages.

\subsection{In the scope of the use of the FDDQL}

Under no circumstances may Olivier Chassany, Park Davis, France, and Mapi Values, France or Mapi Research Trust be held liable for direct or consequential damage resulting from the use of the FDDQL.

Neither Mapi Research Trust nor Mapi Research Institute may be held liable for the consequences resulting from the use of an original instrument and/or its translations not produced by Mapi Research Trust or Mapi Research Institute.

\subsection{In the event of non-renewal of this Agreement}

In the event of non-renewal of this Agreement by Mapi Research Trust for any cause or failure by Mapi Research Trust to conclude a new agreement with "User" upon the expiry of this Agreement, Mapi Research Trust will have no liability for payment of any damages and/or indemnity to "User"

\section{Term and termination}

This agreement shall be effective as the date of its signature by "User" and shall continue until the term of the study mentioned above in the section "Context of FDDQL Use".

Either party may terminate this Agreement immediately upon providing written notice to the other party in the event of: (a) the other party's unexcused failure to fulfill any of its material obligations under this Agreement or (b) upon the insolvency or bankruptcy of, or the filing of a petition in bankruptcy or similar arrangement by the other party.

Upon expiration or termination of this Agreement Mapi Research Trust may retain in its possession confidential information it acquired from FDDQL while under contract.

\section{Assignment}

This Agreement and any of the rights and obligations of "User" are specific to the "User" and cannot be assigned or transferred by "User" to any third party or by operation of law, except with the written consent of Mapi Research Trust notified to "User".

\section{Separate Agreement}

This Agreement holds for the above mentioned study only. The use of the FDDQL in any additional study of the "User" will require a separate agreement.

\section{Entire Agreement, Modification, Enforceability}

The entire agreement hereto is contained herein and this Agreement cancels and supersedes all prior agreements, oral or written, between the parties hereto with the respect to the subject matter hereto.

This Agreement or any of its terms may not be changed or amended except by written document and the failure by either party hereto to enforce any or all of the provision(s) of this Agreement shall not be deemed a waiver or an amendment of the same and shall not prevent future enforcement thereof.

If any one or more of the provisions or clauses of this Agreement are adjudged by a court to be invalid or unenforceable, this shall in no way prejudice or affect the binding nature of this Agreement as a whole, or the validity or enforceability of each/and every other provision of this Agreement.

\section{Governing law}

This Agreement shall be governed by and construed in accordance with the laws of France. 


\section{Forum}

Any disputes arising from this Agreement, including without limitation its validity, interpretation performance, and/or termination and its consequences shall be resolved by the tribunal de commerce of LYON (FRANCE).

AGREED

User's Signature (handwritten):

Company/Organisation Stamp (if applicable):

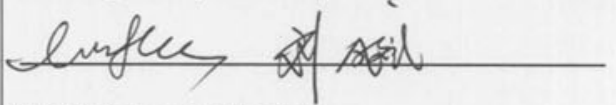

Title: Professor and director

Company/Organisation: Gastroenterology department, the first affiliated Hospital of Guangzhou University of Chinese Medicine.

Date: $23 / 12 / 2008$ 


\title{
Appendix 2: The Translation-Agreement of the Functional Digestive Disorders Quality of Life Questionnaire
}

TRANSLATION AGREEMENT

\author{
FUNCTIONAL DIGESTIVE DISORDERS QUALITY OF LIFE QUESTIONNAIRE (FDDQL) \\ Date: $\quad 23 / 12 / 2008$ \\ User first name: Liu \\ User Last Name: Fengbin
}

User title: Professor and director

User position: the Director of Gastroenterology Department, the first Affiliated Hospital of Guangzhou University of Chinese Medicine

User details:

- Address: 16\#,Jichang Road, Guangzhou City, Guangdong Province, 510405, P.R.China

- Country: P.R.China

- Phone number. +862036591363

- Fax number:None

- E-mail address: liufb163@163.com; hyada134@163.com

This Agreement is made between Prof.Liu and Mapi Research Trust. Mapi Research Trust, on behalf of Olivier Chassany, Parke Davis, France, and Mapi Values, France, copyright owners in the FDDQL, authorizes Prof.Liu to translate the FDDQL into Chinese in the framework of study/project ID NO. subject to the following conditions:

1. Olivier Chassany, Parke Davis, France, and Mapi Values, France own all copyright in the FDDQL and in all FDDQL versions including but not limited to existing and future translations of the FDDQL. Prof.Liu shall not claim any ownership on the translation(s) that Prof.Liu has produced.

2. Prof.Liu acknowledges Olivier Chassany, Parke Davis, France, and Mapi Values, France's copyright in the FDDQL and shall not contest such copyright or perform any act or omission adverse to such exclusive right. Further Prof.Liu acknowledges that Olivier Chassany, Parke Davis, France, and Mapi Values, France hold the unfettered right to use, reproduce and exploit the aforesaid translation(s), throughout the world, for its full term without any cost or conditions.

3. Each new translation must undergo a full linguistic validation process according to standard recognized methodology of translation, as described in Acquadro C, Conway K; Giroudet C, Mear I. Linguistic Validation Manual for Patient-Reported Outcomes (PRO) Instruments. Mapi Research Institute, 2004.

The recommended methodology includes the following steps:

- Forward translation

- Backward translation

- Cognitive debriefing

- International harmonization (if more than one language is involved).

- Proofreading

- Report

3.1. Each step of the linguistic validation described above has to be validated by Olivier Chassany, co-author of the FDDQL.

3.2. In the context of commercial studies or any project funded by the pharmaceutical industry and to follow the above mentioned criteria, the assistance of a company specialized in translation/linguistic validation of PRO questionnaires is required. User is free to work with the translation company of his/her choice provided that the above mentioned methodology is followed. 
3.3. In the context of academic translations, the assistance of an accredited academic team/company specialized and recognized in translation is required. Prof.Liu acknowledges that the linguistic validation guidelines provided by the Mapi Research Trust have to be followed.

3.4. Academic translations are considered for academic research and evaluation purposes only. Under no circumstances can they be used for commercial or international studies, or dispatch it to any third party for commercial or other use.

4. A copy of the final version of each new translation must be provided to Mapi Research Trust and must be made available in a double format, i.e. a read-only file format (PDF) and a standard, exploitable format so that one can have the possibility to check whether the usable format has not undergone any font or character modifications during possible conversions.

5. The translation shall be provided along with a certificate of translation describing the process used to produce the translation.

6. Any new translation must be made available to third parties through Mapi Research Trust.

7. USER is required to place the authors' copyright notice "FDDQL○ 1999 Olivier Chassany, Parke Davis, France, and Mapi Values, France, All rights reserved" on each new translation of the questionnaire. The copyright notice shall be translated in the target language, with respect to the local copyright regulation.

8. Academic translators are responsible for the translations they produce or have produced and provide to Mapi Research Trust. They remain accountable for fixing any spelling/formatting errors identified after delivery.

9. The use of the FDDQL, including but not limited to the above mentioned new translation(s), is subject to a separate agreement. User acknowledges that a User Agreement was signed with Mapi Research Trust for the use of the FDDQL in the framework of study ID NO. (Study/Project ID NO.).

10. If the translated questionnaire is used in a any subsequent study including commercial or international studies, the sponsor must sign a User-Agreement with MAPI Research Trust and must pay the corresponding fee (please refer to the user-agreement).

11. If the translation work is to be abandoned for any reason, Prof.Liu shall notify Mapi Research Trust of such information immediately.

Prof.Liu intends to work on the linguistic validation of the FDDQL developed by Olivier Chassany, Parke Davis, France, and Mapi Values, France into the following language:

Chinese

For use in the following country: P.R. China

expects the linguistic validation process to be performed by:

Gastroenterology department, the first affiliated Hospital of Guangzhou University of Chinese Medicine

and all documents to be ready by: $\quad 05 / 2010$

I hereby acknowledge the information presented in this document and agree to send paper and electronic copies of the final translated version and all reports documenting the translation process to Mapi Research Trust once completed.

Approved and signed for:

Company Gastroenterology department, the first affiliated Hospital of Guangzhou University of Chinese Medicine

Name: LIU Fengbin

Date: $\quad 23 / 12 / 2008$

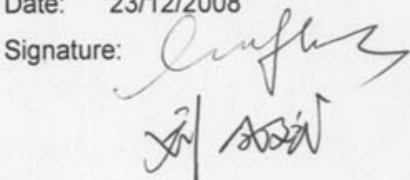

TranslationAgreement FDDQL nonexclusive-03.doc 2 


\section{Appendix 3: The Original English Version of the Functional Digestive Disorders Quality of Life Questionnaire}

\section{QUALITY OF LIFE QUESTIONNAIRE FORFUNCTIONAL DIGESTIVE DISORDERS}

How to complete this questionnaire

The following questions are about your state of health over the past 14 days.

Please respond to all questions by checking only one box per question.

Choose the response which best describes how you feel.

Please respond to all questions even if you think some are similar.

If you do not do certain activities (e.g. sports) check "not applicable"

If you make a mistake, cross out the wrong answer and circle the one that best applies to you.

Please try to complete this questionnaire on your own.

Thank you for your participation.

ACTIVITIES

Over the past 14 days, because of your digestive problems,

1. have you had any difficulties carrying out your daily activities?

Not at all A little bit Moderately Quite a bit Extremely

2. have you had to disrupt your daily activities?

Never Rarely Sometimes Often Always

3. have you had any difficulties carrying out your leisure activities (gardening, walks in the park...)?

Not at all A little bit Moderately Quite a bit Extremely

4. have you had any difficulties focusing, especially when reading or listening to music?

Never Rarely Sometimes Often Always

5. have you felt restricted in performing strenuous physical activities like running, lifting or pushing heavy objects, i.e. pushing a table...?

Not at all A little bit Moderately Quite a bit Extremely Not applicable

Over the past 14 days, because of your digestive problems,

6. has the quality of your work (either at home or on the job) suffered?

Not at all A little bit Moderately Quite a bit Extremely

7. has it taken you longer to perform certain tasks at work (either at home or on the job)?

Not at all A little bit Moderately Quite a bit Extremely

8. have you thought that your digestive problems were preventing you from doing your job as you would like to do it?

Never Rarely Sometimes Often Always

ANXIETY

9. Are you afraid that your digestive problems could get worse in the future?

Not at all A little bit Moderately Quite a bit Extremely

10. Do you fear you may get digestive cancer?

Not at all A little bit Moderately Quite a bit Extremely

11. Are you afraid that the medicine that you have been taking for your digestive problems will become less effective as time goes on?

Not at all A little bit Moderately Quite a bit Extremely Not applicable

Over the past 14 days, 
12. have you been worried about not knowing when the next bout of digestive pains or problems would arise?

Never Rarely Sometimes Often Always

13. has the slightest worsening of your pains or intestinal activity worried you?

Never Rarely Sometimes Often Always

DIET

14. Are you concerned that a change in diet on weekends or while on vacation could trigger your digestive problems?

Not at all A little bit Moderately Quite a bit Extremely Not applicable

15. Do you think you are more sensitive to certain foods than other people?

Not at all A little bit Moderately Quite a bit Extremely

Over the past 14 days, because of your digestive problems,

16. have you felt frustrated about not being able to eat like everyone else?

Never Rarely Sometimes Often Always

17. have you been careful about what you eat or drink?

Never Rarely Sometimes Often Always

18. have you felt it necessary to follow a strict diet?

Never Rarely Sometimes Often Always

19. has it been hard for you to eat in a restaurant or at someone's home?

Never Rarely Sometimes Often Always

SLEEP

Over the past 14 days,

20. despite your digestive problems, have you been able to fall asleep easily?

Never Rarely Sometimes Often Always

21. have you been awakened at night because of digestive pains or problems?

Never Rarely Sometimes Often Always

22. have your digestive problems kept you awake for most of the night?

Never Rarely Sometimes Often Always

DISCOMFORT

23. When you are invited to someone's home or when going out, are you concerned with having flatulence (gas), belching, a rumbling stomach, or an urgent need to have a bowel movement...?

not at all A little bit Moderately Quite a bit Extremely Not applicable

Over the past 14 days,

24. have you been bothered by flatulence (gas)?

Not at all A little bit Moderately Quite a bit Extremely

25. have you been bothered by your stomach rumbling?

Not at all A little bit Moderately Quite a bit Extremely

26. have you been bothered by a bloated stomach?

Not at all A little bit Moderately Quite a bit Extremely 
27. has it been difficult for you to have a bowel movement when not at home?

Not at all A little bit Moderately Quite a bit Extremely Not applicable

Over the past 14 days,

28. have you had to undo your button, loosen your belt or even lie down after meals?

Never Rarely Sometimes Often Always

29. have you avoided wearing tight clothes?

Never Rarely Sometimes Often Always

30. have you been satisfied with your intestinal activity?

Not at all A little bit Moderately Quite a bit Extremely

31. have you been satisfied with your digestion?

Not at all A little bit Moderately Quite a bit Extremely

Please note the following are statements. Please indicate whether you agree or disagree with these statements.

HEALTH PERCEPTIONS

32. I feel that my health is more delicate than other people's.

Totally disagree Mostly disagree Don't know Mostly agree Totally agree

33. I consider my health to be excellent.

Totally disagree Mostly disagree Don't know Mostly agree Totally agree

34. I will have a hearty meal with friends or at family gatherings even if it will make my digestive problems worse.

Totally disagree Mostly disagree Don't know Mostly agree Totally agree

35. Despite my digestive problems, I think that over the next few years, I will be able to achieve the things that matter to me (professional career, family life, retirement...).

Totally disagree Mostly disagree Don't know Mostly agree Totally agree

36. I attach little importance to my digestive pains, even if they bother me in everyday activities.

Totally disagree Mostly disagree Don't know Mostly agree Totally agree

37. Despite my digestive problems I can lead a normal life.

Totally disagree Mostly disagree Don't know Mostly agree Totally agree

COPING

38. I feel that there is nothing I can do to change my digestive problems.

Totally disagree Mostly disagree Don't know Mostly agree Totally agree

39. I feel that I am not in control of my digestive problems.

Totally disagree Mostly disagree Don't know Mostly agree Totally agree

40. I have no idea what I should do when I have my digestive problems.

Totally disagree Mostly disagree Don't know Mostly agree Totally agree

IMPACT OF STRESS

41. I believe that any stress causes my digestive problems.

Totally disagree Mostly disagree Don't know Mostly agree Totally agree

42. Major aggravation triggers my digestive problems.

Totally disagree Mostly disagree Don't know Mostly agree Totally agree

43. Even the least bit of aggravation triggers my digestive problems.

Totally disagree Mostly disagree Don't know Mostly agree Totally agree 
Appendix 4: The Final Chinese Version of the

Functional Digestive Disorders Quality of Life Questionnaire

功能性消化不良生存质量量表 (FDDQL) 中文版

编号:

姓名： 性别：男 女 年龄：职业:

学历: 01 未受教育 02 小学 03 初中 04 高中

05 大专 06 大学 07 大学以上

\section{如何完成此问卷}

下面的问题是关于你最近 14 天的健康状态。

请回答所有问题, 并且每个问题只能选择一个选项。

选择最能描述当前您感觉的选项。

请回答所有问题, 即使您认为一些是相似的。

如果您不做某些活动 (如运动), 请选择 “不适用” 选项。

如果您勾选错了, 请划掉那个选项, 然后把认为适合您的那个选项圈上。

请设法独自地完成这张查询表。

谢谢您的参与。

请根据最近 14 天，由于您的消化系统问题: 


\section{日常活动}

1.您觉得从事一般的日常活动有困难吗?

$\begin{array}{ccccc}\square_{1} & \square_{2} & \square_{3} & \square_{4} & \square_{5} \\ \text { 完全没有 } & \text { 有一点 } & \text { 中度的 } & \text { 相当多 } & \text { 极其多 }\end{array}$

2.您的消化问题会影响您的日常活动吗?

$\begin{array}{ccccc}\square_{1} & \square_{2} & \square_{3} & \square_{4} & \square_{5} \\ \text { 不会 } & \text { 很少会 } & \text { 有时会 } & \text { 经常会 } & \text { 总是会 }\end{array}$

3. 您的消化问题对你进行休闲活动（如养花, 适公园) 有影响吗?

$\begin{array}{ccccc}\square_{1} & \square_{2} & \square_{3} & \square_{4} & \square_{5} \\ \text { 完全没有 } & \text { 有一点 } & \text { 中度的 } & \text { 相当多 } & \text { 极其多 }\end{array}$

4.当您做某件事时（比如读书或听音乐）集中精神困难吗?

$\begin{array}{lcccc}\square_{1} & \square_{2} & \square_{3} & \square_{4} & \square_{5} \\ \text { 不会 } & \text { 很少会 } & \text { 有时会 } & \text { 经常会 } & \text { 总是会 }\end{array}$

5. 当您从事重体力活动（如跑步、提重物等）时会觉得受限制吗?

$\begin{array}{cccccc}\square_{1} & \square_{2} & \square_{3} & \square_{4} & \square_{5} & \square_{6} \\ \text { 完全没有 } & \text { 有一点 } & \text { 中度的 } & \text { 相当多 } & \text { 极其多 } & \text { 不适用 }\end{array}$

6.对您工作或家务的质量有影响吗？

$\begin{array}{ccccc}\square_{1} & \square_{2} & \square_{3} & \square_{4} & \square_{5} \\ \text { 完全没有 } & \text { 有一点 } & \text { 中度的 } & \text { 相当多 } & \text { 极其多 }\end{array}$

7.消化问题使您完成某项工作较从前花的时间更长吗?

$\begin{array}{ccccc}\square_{1} & \square_{2} & \square_{3} & \square_{4} & \square_{5} \\ \text { 完全没有 } & \text { 有一点 } & \text { 中度的 } & \text { 相当多 } & \text { 极其多 }\end{array}$

8.您认为消化问题会使您无法完成你想做的事情吗?

$\begin{array}{cccccc}\square_{1} & \square_{2} & \square_{3} & \square_{4} & \square_{5} & \square_{6} \\ \text { 不会 } & \text { 很少会 } & \text { 有时会 } & \text { 经常会 } & \text { 总是会 } & \text { 不适用 }\end{array}$

忧虑

9. 您担心您的消化问题会变得更差吗?

$\begin{array}{ccccc}\square_{1} & \square_{2} & \square_{3} & \square_{4} & \square_{5} \\ \text { 完全没有 } & \text { 有一点 } & \text { 中度的 } & \text { 相当多 } & \text { 极其多 }\end{array}$


10.您害怕因消化问题而引起肿瘤吗?

$\begin{array}{ccccc}\square_{1} & \square_{2} & \square_{3} & \square_{4} & \square_{5} \\ \text { 完全没有 } & \text { 有一点 } & \text { 中度的 } & \text { 相当多 } & \text { 极其多 }\end{array}$

11.您担心治疗您消化问题的药物会逐渐变得无效吗?

$\begin{array}{cccccc}\square_{1} & \square_{2} & \square_{3} & \square_{4} & \square_{5} & \square_{6} \\ \text { 完全没有 } & \text { 有一点 } & \text { 中度的 } & \text { 相当多 } & \text { 极其多 } & \text { 不适用 }\end{array}$

12.您担心您的消化问题（如疼痛）会反复吗?

$\begin{array}{ccccc}\square_{1} & \square_{2} & \square_{3} & \square_{4} & \square_{5} \\ \text { 不会 } & \text { 很少会 } & \text { 有时会 } & \text { 经常会 } & \text { 总是会 }\end{array}$

13.您消化问题的轻微加重（如疼痛或肠不适）会使您担心吗?

$\begin{array}{ccccc}\square_{1} & \square_{2} & \square_{3} & \square_{4} & \square_{5} \\ \text { 不会 } & \text { 很少会 } & \text { 有时会 } & \text { 经常会 } & \text { 总是会 }\end{array}$

饮食

14.您担心周末或假期的饮食改变会诱发您的消化问题吗?

$\begin{array}{cccccc}\square_{1} & \square_{2} & \square_{3} & \square_{4} & \square_{5} & \square_{6} \\ \text { 完全没有 } & \text { 有一点 } & \text { 中度的 } & \text { 相当多 } & \text { 极其多 } & \text { 不适用 }\end{array}$

15. 您觉得您的胃肠对某些食物比其他人更敏感吗?

$\begin{array}{ccccc}\square_{1} & \square_{2} & \square_{3} & \square_{4} & \square_{5} \\ \text { 完全没有 } & \text { 有一点 } & \text { 中度的 } & \text { 相当多 } & \text { 极其多 }\end{array}$

16. 由于消化不适, 您会因为不像别人那么能吃而感到沮丧吗?

$\begin{array}{lcccc}\square_{1} & \square_{2} & \square_{3} & \square_{4} & \square_{5} \\ \text { 不会 } & \text { 很少会 } & \text { 有时会 } & \text { 经常会 } & \text { 总是会 }\end{array}$

17.您会很小心自己的饮食吗?

$\begin{array}{ccccc}\square_{1} & \square_{2} & \square_{3} & \square_{4} & \square_{5} \\ \text { 不会 } & \text { 很少会 } & \text { 有时会 } & \text { 经常会 } & \text { 总是会 }\end{array}$

18.您会觉得有必要忌口吗?

$\begin{array}{lcccc}\square_{1} & \square_{2} & \square_{3} & \square_{4} & \square_{5} \\ \text { 不会 } & \text { 很少会 } & \text { 有时会 } & \text { 经常会 } & \text { 总是会 }\end{array}$


19. 在餐馆或在别人家吃饭有很不舒服的感觉吗?

$\begin{array}{cccccc}\square_{1} & \square_{2} & \square_{3} & \square_{4} & \square_{5} & \square_{6} \\ \text { 完全没有 } & \text { 有一点 } & \text { 中度的 } & \text { 相当多 } & \text { 极其多 } & \text { 不适用 }\end{array}$

\section{睡眠}

20. 尽管有消化问题, 您还是会很容易入睡吗?
$\square_{1}$
$\square_{2}$
$\square_{3}$
$\square_{4}$
$\square_{5}$
不会
很少会
有时会
经常会
总是会

21. 您会有因胃肠疼痛或不适而经常夜里醒来吗?

$\begin{array}{lcccc}\square_{1} & \square_{2} & \square_{3} & \square_{4} & \square_{5} \\ \text { 不会 } & \text { 很少会 } & \text { 有时会 } & \text { 经常会 } & \text { 总是会 }\end{array}$

22. 您的消化问题会使您几乎彻夜难眠吗?

$\begin{array}{lcccc}\square_{1} & \square_{2} & \square_{3} & \square_{4} & \square_{5} \\ \text { 不会 } & \text { 很少会 } & \text { 有时会 } & \text { 经常会 } & \text { 总是会 }\end{array}$

\section{不适}

23.当您外出或受邀做客时, 您会担心出现胃肠胀气、喛气、胃中辘辘声和腹泻等不适吗?

$\begin{array}{cccccc}\square_{1} & \square_{2} & \square_{3} & \square_{4} & \square_{5} & \square_{6} \\ \text { 完全没有 } & \text { 有一点 } & \text { 中度的 } & \text { 相当多 } & \text { 极其多 } & \text { 不适用 }\end{array}$

24. 您有被胃肠胀气所困扰吗?

$\begin{array}{ccccc}\square_{1} & \square_{2} & \square_{3} & \square_{4} & \square_{5} \\ \text { 完全没有 } & \text { 有一点 } & \text { 中度的 } & \text { 相当多 } & \text { 极其多 }\end{array}$

25. 您有被胃中辘辘声所困扰吗?

$\begin{array}{ccccc}\square_{1} & \square_{2} & \square_{3} & \square_{4} & \square_{5} \\ \text { 完全没有 } & \text { 有一点 } & \text { 中度的 } & \text { 相当多 } & \text { 极其多 }\end{array}$

26. 您有被胃胀满所困扰吗?

$\begin{array}{ccccc}\square_{1} & \square_{2} & \square_{3} & \square_{4} & \square_{5} \\ \text { 完全没有 } & \text { 有一点 } & \text { 中度的 } & \text { 相当多 } & \text { 极其多 }\end{array}$

27.您外出时有排便困难吗?

$\begin{array}{cccccc}\square_{1} & \square_{2} & \square_{3} & \square_{4} & \square_{5} & \square_{6} \\ \text { 完全没有 } & \text { 有一点 } & \text { 中度的 } & \text { 相当多 } & \text { 极其多 } & \text { 不适用 }\end{array}$


28.吃完饭后, 您是否会有因为腹胀满而不得不解开扣子、放松皮带或者躺下才舒服些的情 况吗?
$\square_{1}$
$\square_{2}$
$\square_{3}$
$\square_{4}$
$\square_{5}$
不会
很少会
有时会
经常会
总是会

29. 您会因胃肠胀满而不得不避免穿窄身的衣服吗?

$\begin{array}{ccccc}\square_{1} & \square_{2} & \square_{3} & \square_{4} & \square_{5} \\ \text { 不会 } & \text { 很少会 } & \text { 有时会 } & \text { 经常会 } & \text { 总是会 }\end{array}$

30. 您对您的肠运动功能满意吗?

$\begin{array}{ccccc}\square_{1} & \square_{2} & \square_{3} & \square_{4} & \square_{5} \\ \text { 完全不满意 } & \text { 有一点满意 } & \text { 中度的 } & \text { 相当满意 } & \text { 极其满意 }\end{array}$

31. 您对您的消化功能满意吗?

$\begin{array}{ccccc}\square_{1} & \square_{2} & \square_{3} & \square_{4} & \square_{5} \\ \text { 完全不满意 } & \text { 有一点满意 } & \text { 中度的 } & \text { 相当多满意 } & \text { 极其满意 }\end{array}$

请注意下列说法并请选择选项:

\section{健康感觉}

32. 我觉得我比别人体弱。

$\begin{array}{ccccc}\square_{1} & \square_{2} & \square_{3} & \square_{4} & \square_{5} \\ \text { 完全不同意 } & \text { 大多不同意 } & \text { 不清楚 } & \text { 大多同意 } & \text { 完全同意 }\end{array}$

33.我认为我的健康状况非常好。

$\begin{array}{ccccc}\square_{1} & \square_{2} & \square_{3} & \square_{4} & \square_{5} \\ \text { 完全不同意 } & \text { 大多不同意 } & \text { 不清楚 } & \text { 大多同意 } & \text { 完全同意 }\end{array}$

34.与朋友或家人聚餐时, 就算使我的病情加重, 我也会吃很多。

$\begin{array}{ccccc}\square_{1} & \square_{2} & \square_{3} & \square_{4} & \square_{5} \\ \text { 完全不同意 } & \text { 大多不同意 } & \text { 不清楚 } & \text { 大多同意 } & \text { 完全同意 }\end{array}$

35.即使有消化问题, 我觉得未来几年, 也不会影响到我既定目标的实现（职业生涯、家庭 生活, 退休…)

$\begin{array}{ccccc}\square_{1} & \square_{2} & \square_{3} & \square_{4} & \square_{5} \\ \text { 完全不同意 } & \text { 大多不同意 } & \text { 不清楚 } & \text { 大多同意 } & \text { 完全同意 }\end{array}$

36.即使胃肠疼痛或不适影响我的日常活动, 我也很少关注它。

$\begin{array}{ccccc}\square_{1} & \square_{2} & \square_{3} & \square_{4} & \square_{5} \\ \text { 完全不同意 } & \text { 大多不同意 } & \text { 不清楚 } & \text { 大多同意 } & \text { 完全同意 }\end{array}$


37. 即使有消化问题, 我也能正常生活。
$\square_{1}$
$\square_{2}$
$\square_{3}$
$\square_{4}$
$\square_{5}$
完全不同意 大多不同意
不清楚
大多同意
完全同意

\section{疾病控制}

38. 我觉得我对改善自己的消化问题无能为力。

$\begin{array}{ccccc}\square_{1} & \square_{2} & \square_{3} & \square_{4} & \square_{5} \\ \text { 完全不同意 } & \text { 大多不同意 } & \text { 不清楚 } & \text { 大多同意 } & \text { 完全同意 }\end{array}$

39.我觉得我的消化问题没有被控制。

$\begin{array}{ccccc}\square_{1} & \square_{2} & \square_{3} & \square_{4} & \square_{5} \\ \text { 完全不同意 } & \text { 大多不同意 } & \text { 不清楚 } & \text { 大多同意 } & \text { 完全同意 }\end{array}$

40.当出现消化问题时我不知道该怎么做。

$\square_{1}$

完全不同意 $\square_{2}$

大多不同意 $\square_{3}$

不清楚 $\square_{4}$

大多同意 $\square_{5}$

完全同意

\section{压力}

41. 我认为任何压力都会引起我的胃肠不适。

$\begin{array}{ccccc}\square_{1} & \square_{2} & \square_{3} & \square_{4} & \square_{5} \\ \text { 完全不同意 } & \text { 大多不同意 } & \text { 不清楚 } & \text { 大多同意 } & \text { 完全同意 }\end{array}$

42. 较重要的烦恼事情会引起我的消化问题。

$\begin{array}{ccccc}\square_{1} & \square_{2} & \square_{3} & \square_{4} & \square_{5} \\ \text { 完全不同意 } & \text { 大多不同意 } & \text { 不清楚 } & \text { 大多同意 } & \text { 完全同意 }\end{array}$

43. 即使一点点烦恼事都会引起我的消化问题。

$\begin{array}{ccccc}\square_{1} & \square_{2} & \square_{3} & \square_{4} & \square_{5} \\ \text { 完全不同意 } & \text { 大多不同意 } & \text { 不清楚 } & \text { 大多同意 } & \text { 完全同意 }\end{array}$




\section{Appendix 5: The User Guide for the Chinese Version of the Functional Digestive Disorders Quality of Life Questionnaire}

功能性消化不良生存质量量表（FDDQL）中文版使用手册

一、量表的描述及评分原则

功能性消化不良量表中文版含条目 43 条, 由 8 个领域构成。量表结构如表 1 所示:

表 1 功能性消化不良量表（FDDQL）中文版结构

\begin{tabular}{|c|c|c|c|}
\hline 领域 & 代码 & 条目数 & 条目范围 \\
\hline $\begin{array}{c}\text { 日常活动 } \\
\text { (ACTIVITIES) }\end{array}$ & $\mathrm{DA}$ & 8 & $1-8$ \\
\hline $\begin{array}{c}\text { 忧虑 } \\
\text { (ANXIETY) }\end{array}$ & AN & 5 & $9-13$ \\
\hline $\begin{array}{c}\text { 饮食 } \\
\text { (DIET) }\end{array}$ & DI & 6 & $14-19$ \\
\hline $\begin{array}{c}\text { 睡眠 } \\
\text { (SLEEP) }\end{array}$ & SL & 3 & $20-22$ \\
\hline $\begin{array}{c}\text { 不适 } \\
\text { (DISCOMFORT) }\end{array}$ & DT & 9 & $23-31$ \\
\hline $\begin{array}{c}\text { 健康感觉 } \\
\text { (HEALTH } \\
\text { PERCEPTIONS） }\end{array}$ & HP & 6 & $32-37$ \\
\hline $\begin{array}{l}\text { 疾病控制 } \\
\text { (COPING WITH } \\
\text { DISEASE) }\end{array}$ & $\mathrm{CD}$ & 3 & $38-40$ \\
\hline $\begin{array}{c}\text { 压力 } \\
\text { (IMPACT OF STRESS) }\end{array}$ & IS & 3 & $41-43$ \\
\hline
\end{tabular}

功能性消化不良 (FDDQL) 包含 43 个条目, 分 8 个领域, 即日常活动 (Q1-Q8)、 忧虑 (Q9-Q13)、饮食 (Q14-Q19)、睡眠 (Q20-Q22)、不适 (Q23-Q31)、疾病处理 (Q32-Q37)、疾病控制 (Q38-Q40) 和压力 (Q41-Q43)。在这 43 个条目中, 条目 5, $8,11,14,19,23,27$ 分为六个等级, 分别为: 完全没有/不会, 有一点/很少 会, 中度的/有时会, 相当多/经常会, 极其多/总是会, 不适用, 根据其回答的 选项, 计分为 1 分到 6 分; 其他各个条目 (除条目 20,30, 31, 33, 34, 35, 36,37 ) 分为五个等级, 分别计分为 1 分到 5 分; 条目 $20,30,31,33,34$, $35,36,37$ 分为五个等级, 计分为 6 -原始分, 将各个领域所包括的条目得分相

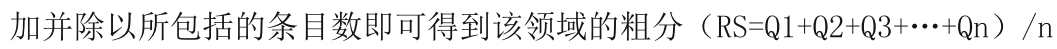

同时为了计算各领域得分可以相互比较及评定量表的总分, 根据原量表作者 提供的计分方法, 尚需变换公式进行计算, 具体如下:

八个领域各自评分 $=100-[(\mathrm{RS}-1) * 25]$

量表总分 $(\mathrm{GS})=100-[(\mathrm{RS}-1) * 25]$; 
而根据量表计分规则中的规定：计算量表总分时应将压力（IMPACT OF STRESS）领域项排除。如果条目 $5,8,11,14,19,23,27$ 中记 6 分条目数 > 1, 则 SL、CD、IS 的计分将丢弃; 若 $>2$ 则 AN 计分将丢弃; 若 $>3$ DI、HP 计分将丢 弃; 若 > 4 则 DA、DT 计分将丢弃。除了压力 (IS) 领域, 其他七个领域中, 如果 有一个领域的计分被丢弃, 则该量表不计总分。该量表说明了各个领域的计算得 分越高, 表明该领域的生存质量越好, 反之计算得分越低, 说明该领域生存质量 越差; 计算量表总分越高, 说明总体生存质量越高, 反之则越差。

二、使用建议

1. 量表用途

本量表初步适用于国内功能性消化不良的临床疗效评价。可通过本量表测评 比较不同治疗方案、同一治疗方案前后的患者报告的结局指标, 从而判断治疗方 案对疾病的干预效果和不良反应, 帮助选择更为优越的个体化治疗方案, 进行多 中心临床科学研究。

2. 应用中的注意事项

2. 1 研究的时间跨度

应根据研究目的决定量表测定的时间和次数, 在临床试验中, 必须在治疗前 做一次基线调查作为个体自身的对照, 对于病情发生变化或者停止治疗的患者的 具体测定方法必须在事前在设计方案中注明。

测量的次数应该尽量减少, 以避免出现过多的缺失数据。

2. 2 研究对象的代理人

为能够真正反应患者自我感受的生存质量, 原则上量表应由患者本人独立阅 读填写。

2. 3 现场调查的质量控制

在开始现场调查前, 需要对调查员进行规范化培训, 使调查员对量表中的每 一个问题都有一个统一的认识。首先由调查员各自认真填写一次调查表, 了解调 查员可能遇到的问题, 由主要研究者对量表的每一个条目进行解释并解答问题。

然后，调查员之间反复互相 “调查”, 直到所有调查员对量表没有疑义。

调查员经过培训, 熟悉量表中每一条目的含义, 形成统一规范的解释, 以相 对统一的方式提问, 使被测定对象乐意如实回答, 避免不恰当的询问方式而导致 的歧义, 以保证测定结果的真实性。

2. 4 资料的完整性

调查员回收量表时要注意每一份量表是否有空项、漏项, 能补的尽量补上。 处理缺失资料必须严格遵循事先明确规定的原则。

当一份问卷中有 $20 \%$ 的数据缺失时, 该问卷视为便作废。如果一个方面中 有一个问题缺失, 则以该方面中另外条目的平均分代替该缺失条目的得分。如果 一个方面中有一半以上条目缺失, 则不计算该方面得分, 可以用其它方面的平均 分代替。

2. 5 研究对象的依从性

依从性直接影响测定结果的准确性。应该从患者的角度出发, 说明调查对患 者的治疗有利, 使其能够积极配合, 并取得亲友的谅解与支持, 通过他们的督促, 提高患者的配合和依从。

3. 版权归属

本量表由刘凤斌教授等翻译研制, 版权归属刘凤斌教授所有。该量表为免费 使用, 但在使用前须征得作者同意, 签署使用协议书, 否则属侵权行为。

通讯地址：广州中医药大学第一附属医院二内科, 510405

E-mail: liufb163@163.com 


\section{References}

1. Tack J, Talley NJ, Camilleri M, et al. Functional gastroduodenal disorders. Gastroenterology. 2006;130:1466-1479.

2. Mahadeva S, Goh KL. Epidemiology of functional dyspepsia: a global perspective. World J Gastroenterol. 2006;12:2661-2666.

3. Shaib Y, El-Serag HB. The prevalence and risk factors of functional dyspepsia in a multiethnic population in the United States. Am J Gastroenterol.. 2004;99:2210-2216.

4. Brun Rita, Kuo Braden. Functional dyspepsia. Therap Adv Gastroenterol. 2010;3:145-164.

5. Agreus L, Borgquist L. The cost of gastro-oesophageal reflux disease, dyspepsia and peptic ulcer disease in Sweden. Pharmacoeconomics. 2002;20:347-355.

6. Martin C, Marquis P, Bonfils S. A quality of life questionnaire adapted to duodenal ulcer therapeutic trials. Scand J Gastroenterolgy. 1994;206:40.

7. Wiklund IK, Junghard O, Grace E, et al. Quality of life in reflux and dyspepsia patients. Psychometric documentation of a new disease-specific questionnaire (QOLRAD). Eur J Surg Suppl. 1998;583:41-49.

8. Chassany O, Marquis P, Scherrer B, et al. Validation of a specific quality of life questionnaire for functional digestive disorders. Gut. 1999;44:527-533.

9. Chassany O, Bergmann JF. Quality of life in irritable bowel syndrome, effect of therapy. Eur J Surg Suppl. 1998;583:81-86.

10. Bamfi F, Olivieri A, Arpinelli F, et al. Measuring quality of life in dyspeptic patients: development and validation of a new specific health status questionnaire: final report from the Italian QPD project involving 4000 patients. $A m \quad J$ Gastroenterol. 1999;94:730-738.

11. Talley NJ, Haque M, Wyeth JW, et al. Development of a new dyspepsia impact scale: the Nepean Dyspepsia Index. Aliment Pharmacol Ther. 1999;13:225-235.

12. Rabeneck L, Cook KF, Wristers K, Souchek J, Menke T, Wray NP. SODA (severity of dyspepsia assessment): a new effective outcome measure for dyspepsia-related health. $J$ Clin Epidemiol. 2001;54:755-765.

13. Min-hu C, Bi-hui Z, Chu-jun L, Xiao-zhong P, Pin-jin H. An Epidemiological study on dyspepsia in Guangdong area. Chin J Intern Med. 1998;37:312-314.
14. Buzas GM. Assessment of quality of life in functional dyspepsia. Validation of a questionnaire and its use in clinical practice. Orv Hetil. 2004;145:687-692.

15. Sabate JM, Veyrac M, Mion F, et al. Relationship between rectal sensitivity, symptoms intensity and quality of life in patients with irritable bowel syndrome. Aliment Pharmacol Ther. 2008;28:484-490.

16. Schneider A, Weiland C, Enck P, et al. Neuroendocrinological effects of acupuncture treatment in patients with irritable bowel syndrome. Complement Ther Med. 2007;15:255-263.

17. Schneider A, Enck P, Streitberger K, et al. Acupuncture treatment in irritable bowel syndrome. Gut. 2006;55:649-654.

18. Huang YD. Development and evaluation of the chronic gastritis subscale in gastroenteric disease PRO scale (SSDPRO-CG). Guangzhou: Guangzhou University of Chinese Medicine; 2009.

19. Brown GTL, Glasswell K, Harland D. Accuracy in the scoring of writing: studies of reliability and validity using a new zeal and writing assessment system. Assess Writi. 2004;9:105-121.

20. Cheung GW, Rensvold RB. Evaluating goodness-of-fit indexes for testing measurement invariance. Struct Equ Model. 2002;9:233-255.

21. Rasch G. Studies in mathematical psychology: probabilistic models for some intelligence and attainment tests. Denmark: Danish Institute for Educational Research; 1960.

22. Masters GN. A Rasch model for partial credit scoring. Psychometrika. 1982;47:149-174.

23. Joreskog KG, Sorbom D. LISREL 8.7 for Windows [computer software]. Lincolnwood, IL: Scientific Software International; 2004.

24. Andrich, D. Rasch unidimensional measurement models (RUMM) 2020 (Version 4.0). Perth: Rumm Laboratory Pty Ltd; 2003.

25. Buzás GM. Quality of life in patients with functional dyspepsia: short- and long-term effect of Helicobacter pylori eradication with pantoprazole, amoxicillin, and clarithromycin or cisapride therapy: a prospective, parallel-group study. Curr Ther Res. 2006;67:305-320. 